\title{
Ice formation and development in aged, wintertime cumulus over the UK: observations and modelling
}

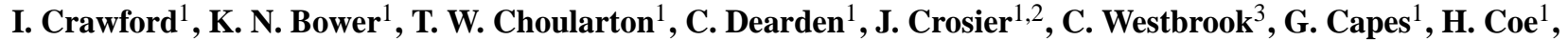 \\ P. J. Connolly ${ }^{1}$, J. R. Dorsey ${ }^{1,2}$, M. W. Gallagher ${ }^{1}$, P. Williams ${ }^{1}$, J. Trembath ${ }^{4}$, Z. Cui ${ }^{5}$, and A. Blyth ${ }^{2,5}$ \\ ${ }^{1}$ Centre for Atmospheric Science, SEAES, University of Manchester, Manchester, UK \\ ${ }^{2}$ National Centre for Atmospheric Science, Manchester, UK \\ ${ }^{3}$ Department of Meteorology, University of Reading, Reading, UK \\ ${ }^{4}$ Facility for Airborne Atmospheric Measurements, Cranfield University, Bedfordshire, UK \\ ${ }^{5}$ School of Earth and Environment, University of Leeds, Leeds, UK
}

Correspondence to: I. Crawfodr (i.crawford@manchester.ac.uk)

Received: 12 October 2011 - Published in Atmos. Chem. Phys. Discuss.: 16 November 2011

Revised: 30 April 2012 - Accepted: 21 May 2012 - Published: 7 June 2012

\begin{abstract}
In situ high resolution aircraft measurements of cloud microphysical properties were made in coordination with ground based remote sensing observations of a line of small cumulus clouds, using Radar and Lidar, as part of the Aerosol Properties, PRocesses And InfluenceS on the Earth's climate (APPRAISE) project. A narrow but extensive line ( $\sim 100 \mathrm{~km}$ long) of shallow convective clouds over the southern UK was studied. Cloud top temperatures were observed to be higher than $-8^{\circ} \mathrm{C}$, but the clouds were seen to consist of supercooled droplets and varying concentrations of ice particles. No ice particles were observed to be falling into the cloud tops from above. Current parameterisations of ice nuclei (IN) numbers predict too few particles will be active as ice nuclei to account for ice particle concentrations at the observed, near cloud top, temperatures $\left(-7.5^{\circ} \mathrm{C}\right)$.

The role of mineral dust particles, consistent with concentrations observed near the surface, acting as high temperature IN is considered important in this case. It was found that very high concentrations of ice particles (up to $100 \mathrm{~L}^{-1}$ ) could be produced by secondary ice particle production providing the observed small amount of primary ice (about $0.01 \mathrm{~L}^{-1}$ ) was present to initiate it. This emphasises the need to understand primary ice formation in slightly supercooled clouds. It is shown using simple calculations that the Hallett-Mossop process (HM) is the likely source of the secondary ice.

Model simulations of the case study were performed with the Aerosol Cloud and Precipitation Interactions Model (ACPIM). These parcel model investigations confirmed the
\end{abstract}

HM process to be a very important mechanism for producing the observed high ice concentrations. A key step in generating the high concentrations was the process of collision and coalescence of rain drops, which once formed fell rapidly through the cloud, collecting ice particles which caused them to freeze and form instant large riming particles. The broadening of the droplet size-distribution by collisioncoalescence was, therefore, a vital step in this process as this was required to generate the large number of ice crystals observed in the time available.

Simulations were also performed with the WRF (Weather, Research and Forecasting) model. The results showed that while HM does act to increase the mass and number concentration of ice particles in these model simulations it was not found to be critical for the formation of precipitation. However, the WRF simulations produced a cloud top that was too cold and this, combined with the assumption of continual replenishing of ice nuclei removed by ice crystal formation, resulted in too many ice crystals forming by primary nucleation compared to the observations and parcel modelling.

\section{Introduction}

Clouds and their interaction with radiation play an important part in the earth's climate. The formation of cloud particles and their interactions with aerosol are highly uncertain, with 
Table 1. Summary of constant altitude runs performed by the FAAM BAe146 aircraft in the operational area to the west of Chilbolton on 22 January 2009, flight reference B425, indicating start and end times of run, mean altitude and temperature of run and direction of run with respect to CFARR.

\begin{tabular}{cccccc}
\hline Reference & Start Time (UTC) & End Time (UTC) & Altitude $^{\mathrm{a}}(\mathrm{km})$ & Temperature $^{\mathrm{b}}$ & Direction $^{\text {Dind }}$ \\
\hline R1 & $13: 17: 02$ & $13: 41: 02$ & 1.30 & $-1.0( \pm 0.1)$ & inbound \\
R2 & $13: 43: 00$ & $13: 52: 09$ & 0.75 & $3.7( \pm 0.3)$ & outbound \\
R3 & $13: 56: 07$ & $14: 15: 21$ & 1.26 & $-3.5( \pm 0.3)$ & inbound \\
R4 & $14: 16: 45$ & $14: 29: 14$ & 1.93 & $-5.7( \pm 0.3)$ & outbound \\
R5 & $14: 32: 33$ & $14: 50: 59$ & 2.24 & $-7.1( \pm 0.3)$ & inbound \\
R6 & $14: 50: 59$ & $15: 03: 40$ & 2.54 & $-4.5( \pm 0.4)$ & outbound \\
R7 & $15: 04: 49$ & $15: 23: 32$ & 2.20 & $-4.8( \pm 0.1)$ & inbound \\
\hline
\end{tabular}

${ }^{a}$ Mean value from GPS receiver. ${ }^{b}$ Mean value from de-iced Rosemount sensor.

the formation and evolution of mixed phase and ice clouds being particularly poorly understood (Penner et al., 2001).

Consequently there has been extensive work over the past few years to explain the observed numbers of ice crystals within clouds (Phillips et al., 2008; Connolly et al., 2009; DeMott et al., 2010). These studies have been motivated partially by observations of ice in clouds from field campaigns and also by the need to develop parameterisations within atmospheric models. One field study in particular, which was based in the Florida region, noted the glaciation of an altocumulus cloud at $-5^{\circ} \mathrm{C}$ and correlated this to dust from the Sahara which had advected into the region by long range transport in easterly winds over the Atlantic (Sassen et al., 2003). They postulated that the dust may have been acting as an effective ice nucleus at these high temperatures.

Dust particles are generally considered to be efficient IN however, more recent field and laboratory investigations have suggested desert dusts are not particularly effective IN at temperatures higher than $\sim-15^{\circ} \mathrm{C}$. For instance, in a study involving lidar depolarisation measurements of short lived alto-cumulus clouds over Morocco, Ansmann et al. (2008) noted that ice was hardly ever observed in these clouds when the temperature was higher than $-20^{\circ} \mathrm{C}$, and even then almost never when liquid water was not also observed to be present first. Ansmann et al.'s (2008)study highlights that, in the atmosphere, ice nucleation at relatively high temperatures mainly acts when liquid water is present first, rather than by the heterogeneous deposition mechanism, and that nucleation on desert dust occurs once the temperature is lower than roughly $-20^{\circ} \mathrm{C}$.

A four year remote sensing study by Westbrook and Illingworth (2011) found that $95 \%$ of the ice particles formed in layer clouds over the southern UK at $T>-20^{\circ} \mathrm{C}$ were formed in supercooled liquid clouds. The likely candidates that may describe such ice nucleation are: (i) condensationfreezing; (ii) immersion-freezing or contact nucleation. Ansmann et al.'s (2008) study was subsequently backed up by laboratory studies on a range of desert dust particles e.g. Connolly et al. (2009), who showed that three different dusts nucleated ice in appreciable amounts at $T \sim-20{ }^{\circ} \mathrm{C}$ and that there was no significant nucleation if liquid water did not form on the dust first. To aid the discussion here we will refer to "high" temperature ice nucleation as ice nucleation at temperatures $T>-10^{\circ} \mathrm{C}$.

The ability of biological particles to potentially act as more effective IN than dust at high temperatures has also been considered. Such particles include bacteria, pollen and fungal spores, which are assessed in this paper using ground based measurements of biological aerosol.

Existing ice nucleation parameterisations that have been used to quantify numbers of atmospheric ice nuclei at high temperatures typically predict fairly low numbers of ice nuclei (IN). For instance, the widely used Meyers et al. (1992) scheme, for condensation/deposition nucleation, predicts that at water saturation there are $1 \mathrm{~L}^{-1}$ of ice crystals at $-10^{\circ} \mathrm{C}$ and $9 \mathrm{~L}^{-1}$ at $-20{ }^{\circ} \mathrm{C}$.

More recently, an ice nucleation parameterisation was developed by DeMott et al. (2010) that depends on the number of aerosol larger than $0.5 \mu \mathrm{m}$ in diameter and the temperature. If we consider a typical continental distribution of aerosols, described by lognormal distribution parameters of $\sigma_{g}=2.03, D_{N}=0.069 \mu \mathrm{m}, N_{L}=1.3 \times 10^{4} \mathrm{~cm}^{-3}$ (Whitby, 1978 ), then the number of aerosols larger than $0.5 \mu \mathrm{m}$ is $\sim 33 \mathrm{~cm}^{-3}$ and the corresponding number of ice crystals predicted by the new scheme is $0.3 \mathrm{~L}^{-1}$ at $-10{ }^{\circ} \mathrm{C}$ and $9 \mathrm{~L}^{-1}$ at $-20^{\circ} \mathrm{C}$, which is similar to that predicted by the earlier Meyers et al. scheme. Even though the schemes predict relatively few primary IN, there is strong evidence to show that ice crystal concentrations in this temperature regime frequently exceed this by in some cases 4 orders of magnitude (c.f. Table 1 in Mossop, 1978), however, this may be subject to shattering artefacts (McFarquhar et al., 2007). A common explanation is that secondary ice production by the HallettMossop process (HM) produces large numbers of additional ice particles (DeMott et al., 2003; Mossop et al., 1972; Blyth and Latham, 1993; Bower et al., 1996; Hogan et al., 2002; Huang et al., 2009; Crosier et al., 2011). This process occurs during riming at slightly supercooled temperatures $\left(-3{ }^{\circ} \mathrm{C}\right.$ to $-8^{\circ} \mathrm{C}$ ) by rime splintering (Hallett and Mossop, 1974). Following the early work, further investigations proposed 
that the supercooled droplet population must contain droplets smaller than $13 \mu \mathrm{m}$ in diameter and larger than $24 \mu \mathrm{m}$ for the process to occur (Mossop, 1978; Saunders and Hosseini, 2001).

In this study, aerosol measurements, made at a ground based site at the Chilbolton Facility for Atmospheric and Radio Research (CFARR, $1.44^{\circ} \mathrm{W}, 51.14^{\circ} \mathrm{N}$ ), and also onboard the BAe146 Facility for Airborne Atmospheric Measurement (FAAM) aircraft are used to investigate the role of aerosols on the microphysics of a shallow convective cloud in conjunction with radar and lidar measurements.

\section{Sampling strategy}

On 22 January 2009, the microphysical properties of a narrow line of shallow convective clouds were investigated as a line of convection advected towards, and then over, the CFARR remote observations facility. Based at CFARR and used in this study are: (i) a steerable $3 \mathrm{GHz}$ S-band dualpolarisation radar (the Chilbolton Advanced Meteorological Radar, hereafter called CAMRa, Goddard et al., 1994); (ii) a $35 \mathrm{GHz}$ vertically pointing cloud radar; and (iii) a vertically pointing lidar ceilometer $(\lambda=905 \mathrm{~nm})$. The latter two instruments are described in detail by Illingworth et al. (2007). The radars are primarily sensitive to large particles such as drizzle/rain drops and ice particles. Both radars have a Doppler capability. At $3 \mathrm{GHz}, \mathrm{CAMRa}$ is also sensitive to Bragg echos from clear air turbulence. The lidar in contrast is very sensitive to cloud droplets and detects a strong reflection from the base of liquid clouds. However it is also rapidly attenuated within those clouds and can only provide information on the base and precipitation below.

The FAAM BAe146 aircraft (flight reference B425) flew a series of runs at increasing altitude (after an initial penetration at mid-level) to sample the convective cloud at many levels from cloud base to cloud top. These runs are summarised in Table 1. Aircraft operations were restricted by air traffic control to an area to the west of CFARR (see Fig. 1) where the aircraft flew the horizontal legs along a radial of $253^{\circ}$ from CFARR, from overhead the facility to a range of $100 \mathrm{~km}$ out to the west. CAMRa performed a series of Range Height Indicator (RHI) scans along this radial while the $35 \mathrm{GHz}$ radar and lidar ceilometer gathered data vertically overhead. Real-time communication of radar and lidar data to the aircraft allowed coordination of the in situ measurements with key features identified by the remote sensing instrumentation.

The FAAM BAe146 aircraft was fitted with a wide array of cloud spectrometers, meteorological sensors and aerosol and trace gas instruments. $1 \mathrm{~Hz}$ measurements of GPS position, temperature (de-iced and non de-iced Rosemount sensors), ambient pressure and dew point temperature (General Eastern and Buck CR2 chilled mirror hygrometers) were made along with measurements of horizontal and vertical

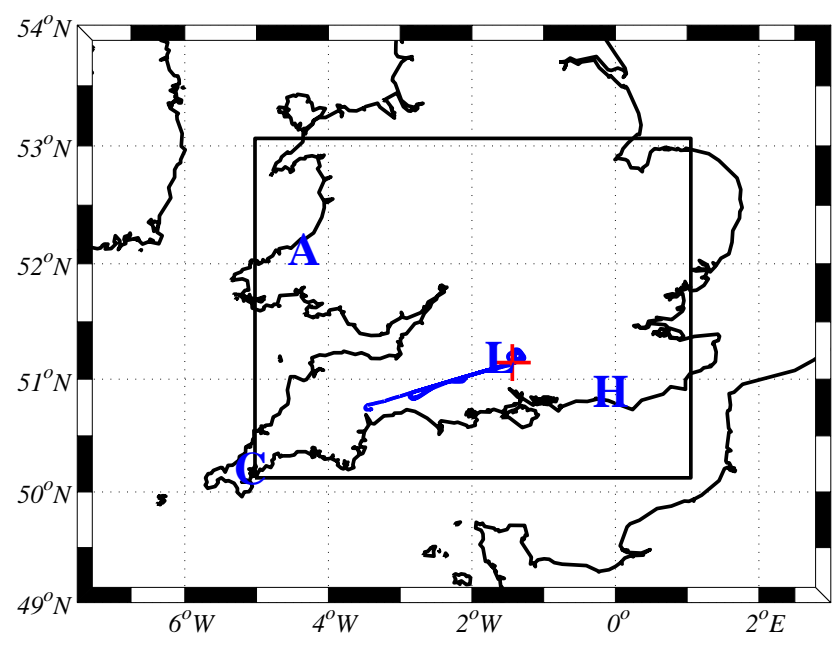

Fig. 1. The 253 degree radial and flight track (blue) of the FAAM BAe146 aircraft on the 22 January 2009 (see Table 1 for details of runs/manoeuvres). Also shown are: the location of CFARR (red cross); the location of radiosonde stations at Cambourne, Larkhill, Herstmonceux and Aberporth (C, L, H and A respectively). The inner box highlights the 3rd or inner domain used in the WRF model sensitivity studies (see Sect. 5.1).

wind speed (also available at $32 \mathrm{~Hz}$ resolution) using a 5-hole pressure port turbulence probe. Additionally, the aerosol particle size distribution was measured with a pylon mounted PMS (Particle Measuring Systems) PCASP-100 (size range $0.1-3.0 \mu \mathrm{m}$ ). Size-segregated and chemically speciated mass composition measurements of sub-micron aerosol $(30 \mathrm{~nm}$ $1 \mu \mathrm{m})$ were made with a Compact Time-of-Flight Aerosol Mass Spectrometer (C-ToF-AMS, Aerodyne Research Inc.) sampling through a Rosemount inlet. Also sampling from the Rosemount inlet was a DMT (Droplet Measurement Technologies) dual column cloud condensation nuclei counter (DMT CCN-200) operated at set supersaturations of $0.12 \%$ and $0.08 \%$ in the separate columns respectively. These data were used to constrain aerosol inputs for a modelling sensitivity study described later.

Cloud droplet number size distribution measurements $(2<$ $d_{\mathrm{p}}<50 \mu \mathrm{m}$ ) were made using a Cloud Droplet Probe (CDP100, DMT), a Cloud and Aerosol Spectrometer (CAS, DMT modified version, size range $\left.0.5<d_{\mathrm{p}}<50 \mu \mathrm{m}\right)$ and a Forward Scattering Spectrometer Probe (FSSP SPP-100, DMT, size range $\left.2<d_{\mathrm{p}}<47 \mu \mathrm{m}\right)$. Because of the possibility of shattering artefacts due to ice particle break up on the inlet in mixed-phase conditions, data from the CAS and FSSP are not considered here and the open path CDP data were used instead (see McFarquhar et al., 2007). The limitations of this instrument are described in greater detail by Lance et al. (2010).

Ice and large cloud droplets together with drizzle droplets were measured using a CCD imaging probe (SPEC CPI) and several 2-D optical array probes (OAPs). These included a 
SPEC Inc 2DS-128-H (herein referred to as 2DS, described in Lawson et al., 2006) and a DMT CIP-100 (Cloud Imaging Probe-100) optical array probe. The 2DS has 128 1-bit elements and a resolution of $10 \mu \mathrm{m}$ covering a particle size range of approximately $10-1280 \mu \mathrm{m}$. Data from this instrument were used for the bulk of the ice and drizzle particle analyses in this paper. The DMT CIP-100 has 64 elements of $100 \mu \mathrm{m}$ resolution each, and thus images particles in the size range $100-6400 \mu \mathrm{m}$. Data from this instrument were used to determine the presence of large precipitation particles. Further details of the instruments, the data processing techniques and corrections applied to the OAP probes to derive ice water contents are provided in Crosier et al. (2011).

In addition to remote sensing measurements, simultaneous detailed ground based aerosol characterisation measurements were also made at the CFARR site during the APPRAISE-Clouds experiment. The FGAM laboratory sea container was deployed at the site enabling intensive ground based measurements to be made at CFARR. The sub-micron aerosol mass composition was determined using a C-ToFAMS (Allan, 2004) and growth factors were found using a Hygroscopic Tandem Differential Mobility Analyser (HTDMA). Accompanying aerosol size distribution measurements were also made with a Scanning Mobility Particle Sizer (SMPS, TSI model 3080L), a GRIMM optical particle counter (model 1.108) and a dual Wavelength Integrating Bio-Aerosol Spectrometer, WIBS-3 (Kaye et al., 2005; Gabey et al., 2010). Air was drawn down through a $6 \mathrm{~m}$ vertical inlet stack and through a $2.5 \mu \mathrm{m}$ cut off cyclone and distributed along the container via a horizontal manifold with isokinetic sampling ports.

No filter samples were taken on the aircraft during this case study, however nucleopore filters were exposed at the ground site, and these were analysed off-line using an automated scanning electron microscope (SEM) and an energy dispersive X-ray (EDX) analysis technique.

\section{Description of models}

Numerical modelling studies can provide useful insight in terms of identifying the dominant microphysical processes that occur in clouds. In this instance, results from numerical models are used to complement the in situ observations specifically to address: (i) whether aerosols measured at the ground are linked to the aerosols within the cloud; and (ii) the issue of how important the Hallett-Mossop process is in terms of the evolution of the boundary layer cloud and subsequent precipitation. The models used are now described.

\subsection{WRF}

Simulations of this case study (B425) were performed using the WRF (Weather Research and Forecasting) model (Version 3.1.1), which was configured in the following way, with
3 nested domains. The outermost domain had a resolution of $9 \mathrm{~km}$ and used a time step of 18 seconds. Subsequent domains were scaled down in a ratio of 3:1 relative to each other. Hence the 2 nd domain had a $3 \mathrm{~km}$ resolution and a 6 second time-step while the innermost domain, focussed on the observation region, was configured with a $1 \mathrm{~km}$ resolution and used a 3 second time-step (Fig. 1 shows the innermost nest). The outer most domain was an 'NAE' type domain whch covered most of the North Atlantic and western/central Europe (356 gridpoints E-W; 196 gridpoints S-N, domain centre $=54.8^{\circ} \mathrm{N}, 6.7^{\circ} \mathrm{W}$ ), while the second domain encompassed the British Isles and the north coast of France (319 gridpoints $\mathrm{E}-\mathrm{W} ; 322$ gridpoints $\mathrm{S}-\mathrm{N}$, domain centre $=52.7^{\circ} \mathrm{N}$, $\left.1.9^{\circ} \mathrm{W}\right)$. The inner most domain covered the observational region (391 gridpoints $\mathrm{E}-\mathrm{W}$; 328 gridpoints $\mathrm{S}-\mathrm{N}$, domain centre $\left.=51.4^{\circ} \mathrm{N}, 2.1^{\circ} \mathrm{W}\right)$.

The model was initialized at 00:00 UTC, 22 January 2009 with National Centre for Environmental Prediction (NCEP) analysis data at 1 degree horizontal resolution. Boundary conditions for the outer domain were also constrained by the NCEP analyses and were updated every $6 \mathrm{~h}$. The analysis data were interpolated onto 80 vertical levels, with a model top at $20 \mathrm{~km}$. The model was configured for one-way nesting such that the inner domains did not feed back onto the parent domains. For the microphysical processes, the Morrison bulk scheme (Morrison et al., 2005) was implemented. This contains dual-moment representations of cloud liquid water, rain, cloud ice, snow and graupel. A gamma distribution is used to describe the cloud droplet size distribution, with a diagnostic relation for the distribution shape parameter; for all other hydrometeors the Marshall and Palmer (1948) distribution is used, which assumes that the rain drops size distribution is exponentially distributed in diameter.

\subsection{ACPIM}

To expand on the WRF study, a 1-D column process model with bin microphysics was used to further explore the microphysical processes occurring within the cloud. The model used is the Aerosol Cloud and Precipitation Interactions Model (ACPIM), developed at the University of Manchester (detailed in Dearden et al., 2011).

In the model, aerosols and water particles are represented by having a 2-D grid representing the number concentration of aerosols of mass $m_{\mathrm{a}}$ and associated water mass $m_{\mathrm{w}}$, (as described by Bott, 2000). This allows a spectrum of particles with different aerosol mass to be formed from the subsequent collision of activated droplets. The aerosol size distribution can be input to the model where the aerosols are assumed to be in equilibrium with the ambient humidity below cloud base and their water content is derived using the ZdanovskiiStokes-Robinson (ZSR) mixing rule (Stokes and Robinson, 1966).

The aerosols grow according to the droplet growth equation (Pruppacher and Klett, 1997) with a condensation 
coefficient of 1 and thermal accommodation coefficient of 0.7. They are transferred along the bin grid using the moving centre bin scheme (Jacobson, 2005). The droplets grow along Kohler curves that are defined from the ZSR mixing rule and the Kelvin equation, using a surface tension equal to that of pure water (Topping et al., 2005); we also utilise ventilation coefficients for heat and vapour, Pruppacher and Klett (1997). Once activated the drops grow by collision and coalescence with the gravitational kernel adapted from Hall (1980). The numerical scheme used to solve the stochastic coalescence equation is a 2-moment scheme conserving number and mass and uses the collision efficiencies based on the Table in Hall (1980). Furthermore, turbulent enhancement of the collision efficiencies of drops with radii of 10 , 20 and 30 microns radius were coded as an option (based on Fig. 14 in Pinsky et al., 1999)

The ice nucleation scheme described by DeMott et al. (2010) is used to initiate ice in the model. This scheme requires a knowledge of the number of aerosols larger than $0.5 \mu \mathrm{m}$ diameter as input, which is diagnosed from the prognostic aerosol bins within the model. Once formed, ice crystals grow from the vapour using the variable aspect ratio, variable density model described by Chen and Lamb (1994a), where the aspect ratio tends towards an inherent growth ratio as observed in the experiments of Fukuta (1969). The variable density reflects the fact that hollow crystals are produced at high supersaturations due to rarefactions in the vapour field, whereas the inherent growth ratio reflects the changes in the deposition coefficients on the different crystallographic faces (Libbrecht, 2005).

Crystals also grow by aggregation, and here an aggregation efficiency of 0.5 has been chosen (which may be too high based on the results of Connolly et al., 2012), while riming efficiencies were set to unity. The size of aggregates of ice crystals is defined by using a fractal-like dimension of 2 such that ice crystal mass is proportional to particle diameter squared (Westbrook et al., 2004), and by specifying that the first aggregation occurs with the two major axes at a $45^{\circ}$ angle, while riming serves to fill in the ice matrix until it forms an ice sphere, whereupon rime mass is deposited to form an ice shell of high density. During riming in the temperature range of -2.5 to $-7.5^{\circ} \mathrm{C}$ ice shards are ejected at a rate equal to 350 splinters per $\mathrm{kg}$ of air per milligram of rime accreted (Hallett and Mossop, 1974).

The calculations carried out by this idealised model can only be taken in a relative sense as the dynamical framework is somewhat unrealistic; nevertheless there is value in doing this as the cloud system in this case study persisted for several hours. It is assumed that ice is formed by primary nucleation and falls against the updraft, but is mostly levitated by the updraft, whereas liquid water is supplied through condensation, which occurs as the air is lifted by the updraft. In this investigation the parcel was lifted at $\sim 0.5 \mathrm{~m} \mathrm{~s}^{-1}$ (based on typical values observed by the lidar) until it reached the $-5^{\circ} \mathrm{C}$ level, following which the ascent of the parcel was ter-
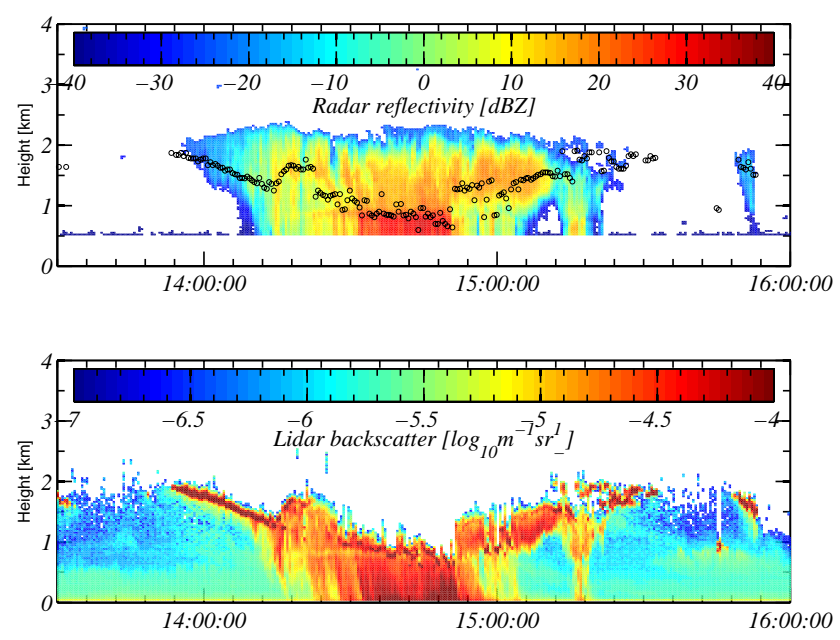

Fig. 2. Time-height contour plot of vertically pointing cloud radar (top panel) and lidar ceilometer (bottom panel) during flight B425. Black markers on the radar time series show the height range of the cloud base detected by the lidar.

minated. Initial conditions for the parcel were: $\mathrm{RH}=95 \%$, $T=+1{ }^{\circ} \mathrm{C}, P=950 \mathrm{mbar}$. This leaves the simulation with the same maximum liquid water content that was observed (see Fig. 3) with ice crystals formed by primary nucleation and growth occurring by vapour deposition, riming and aggregation. Note that the model does not distinguish between cloud drops and warm rain per se, but adopts the convention that drops larger than $80 \mu \mathrm{m}$ diameter are classified as rain and those smaller are cloud particles (as in Seifert and Beheng, 2006).

The ACPIM was used to assess the sensitivity of the glaciation of the cloud to:

- The assumptions of different aerosol mixing states and the effect this has on CCN - as described in Sect. 4.2 and Fig. 6.

- The efficiency of the collision-coalescence process - by specifying either the Hall (1980) collision efficiency or the Pinsky et al. (1999) collision efficiencies.

- The number of primary IN, control, medium and high - by multiplying the DeMott et al. (2010) predicted IN number concentration by a constant: $[1,10,100]$.

\section{Observational results}

The 22 January 2009 saw a region of lower pressure to the north-west of the UK between Iceland and Ireland, with higher pressure to the east over Europe. Earlier, a series of warm fronts crossed the UK; one the previous day and a second in the early morning which was closely followed by a cold front. By midday, prior to take off, troughs were observed over London and the west coast of Ireland. The Met 
Office operational radar network showed two north-south orientated bands of precipitation moving to the east which had precipitated over the UK earlier in the morning. At the time of take-off (13:15 UTC) a thin band of cloud orientated east-west passed over the UK with rainfall rates of up to approximately $3 \mathrm{~mm} \mathrm{~h}^{-1}$. The aircraft profile of temperature and dew point temperature showed there to be a moist layer between 1.6 and $2.2 \mathrm{~km}$ with a dry layer between 2.2 and $2.5 \mathrm{~km}$. This was in good agreement with measurements from the midday radiosonde releases from Cambourne and nearby Larkhill (see Fig. 1 for locations).

\subsection{Cloud properties}

Figure 2 shows a time series of the $35 \mathrm{GHz}$ vertically pointing radar reflectivity and lidar backscatter coefficient at CFARR. The line of cloud measured with the FAAM aircraft started to pass over the radar at around 14:00 UTC. Both the radar and lidar observed drizzle below $1 \mathrm{~km}$ from just before 14:30 UTC until around 15:00 UTC. The reflectivity from this liquid precipitation peaked at around $30 \mathrm{dBZ}$, corresponding to a rain rate of several $\mathrm{mm}$ per hour

The typical cloud properties observed at each level of the series of constant altitude runs (Table 1) are summarized in Fig. 3. The first run R1 (Altitude $=1.30 \mathrm{~km}, T=-1{ }^{\circ} \mathrm{C}$ ) was performed inbound to CFARR in cloud while the reciprocal run R2 was performed outbound from CFARR below cloud (Altitude $=0.75 \mathrm{~km}, T=+2.7^{\circ} \mathrm{C}$ ). $\mathrm{R} 2$ intersected a band of precipitation which contained low concentrations $\left(0.002 \mathrm{~L}^{-1}\right)$ of spheroidal particles with observed volume mode diameters ranging from 200 to $600 \mu \mathrm{m}$ and rain rates of up to $4 \mathrm{~mm} \mathrm{~h}^{-1}$ at a distance of 28 to $50 \mathrm{~km}$ from the Chilbolton observatory. For the majority of the run the CDP droplet number concentration was approximately zero. These observations (e.g. of cloud base height and the presence of drizzle below cloud) are in agreement with the observations from the vertical pointing radar shown in Fig. 2.

Figures 4 and 5 show the altitude of the aircraft overlaid on RHI scans from CAMRa along the $253^{\circ}$ radial for the first in-cloud runs, R1 and R3 (inbound to Chilbolton, Altitude $=1.26 \mathrm{~km}, T=-3.5^{\circ} \mathrm{C}$ ), respectively. Here the RHI scan closest in time to each cloud penetration is chosen for comparison. RHI scans at the times of R2 (below cloud) and R4 (neither shown) found the sampled clouds to be comprised of many cells with radar reflectivity values ranging from approximately 0 to $+30 \mathrm{dBz}$. A bright band in the reflectivity, which signifies the melting layer, was seen in the CAMRa RHI scans from around 13:58 onwards, at an altitude slightly less than $1 \mathrm{~km}$ (see Fig. 5 for R3). There was a corresponding enhancement in differential reflectivity at the same level (not shown) However, the bright band, corresponding to the melting of ice particles as they pass through the $0^{\circ} \mathrm{C}$ level, appears to be quite weak or absent through a lot of the cloud sampled. This suggests that the radar signal is largely dominated by graupel or heavily rimed crystals in the parts pro- ducing the precipitation. This is in contrast to a situation where a much stronger bright band effect would be produced by melting snow flakes passing through this level. Subsequent RHI scans do show some enhancement (over that of R3) in the bright band and differential reflectivity at around this level.

Figures 4 and 5 also show key microphysical measurements made by the aircraft during runs R1 and R3 (the two earliest in cloud runs). During R1, droplet number concentrations of around $150 \mathrm{~cm}^{-3}$ were observed (Fig. 4, second panel). Concentrations of drizzle droplets of approximately $0.03 \mathrm{~L}^{-1}$ were also observed and contribute much less to the condensed water content than the smaller droplets. This run encountered these cells in the line of clouds at an early stage of development. The layer of weak reflectivity in the nearest $30 \mathrm{~km}$ to CFARR (Fig. 4, top) is actually an echo from the base of the inversion, caused by the turbulent mixing of the dry air in the free troposphere and the moister air in the boundary layer (e.g. Morcrette et al., 2007). The potential for turbulent loss of aerosol particles across this inversion is discussed later.

In the second in-cloud run R3 (Fig. 5), the line of clouds was encountered 45 min later (than during R1), and a greater number of cells were intercepted, and many of these cells were more "developed". The radar reflectivity values were higher, and the cloud contained both liquid and ice in varying amounts. Over the first $10 \mathrm{~km}$ of the in-cloud section of the run, the turbulence intensity was relatively lower than the run average (mean vertical velocity, $w=0.15 \mathrm{~m} \mathrm{~s}^{-1}, \sigma=0.55 \mathrm{~m} \mathrm{~s}^{-1}$; in-cloud average, $w=0.55 \mathrm{~m} \mathrm{~s}^{-1}, \sigma=0.71 \mathrm{~m} \mathrm{~s}^{-1}$ ). Continuous cloud was observed from $42.5 \mathrm{~km}$ west of CFARR but the degree of glaciation often varied considerably between adjacent regions and was sometimes seen to undergo rapid transitions as the aircraft passed through cells (and parts of cells) in different stages of evolution and after potentially mixing with air from previous cells (in varying amounts). At the start of the cloud penetration, $42.5 \mathrm{~km}$ out from CFARR, the cloud was mixed phase in nature, containing a few tens per $\mathrm{cm}^{3}$ of droplets and approximately $20 \mathrm{~L}^{-1}$ of rimed ice particles. $38.2 \mathrm{~km}$ from CFARR the ice crystal number doubled and no droplets were detected by the CDP or imaged by the 2DS. Images of crystals in this region showed them to be comprised of rimed columns and aggregates. Directly following this, a region was encountered that comprised of a short burst of high concentrations of supercooled droplets (up to $150 \mathrm{~cm}^{-3}$ ) coexisting with only a few per litre of ice particles, all within a distance of only $400 \mathrm{~m}$. CAMRa gave a weak echo at this position. An extensive mixed phase region containing rimed ice and columns of relatively high ice crystal number concentration $\left(20\right.$ to $\left.100 \mathrm{~L}^{-1}\right)$ then persisted for $8.3 \mathrm{~km}$ before another supercooled region was encountered. This largely supercooled liquid region spanned approximately $11.2 \mathrm{~km}$ but unlike the previous regions, prolonged updrafts were also encountered with typical vertical 

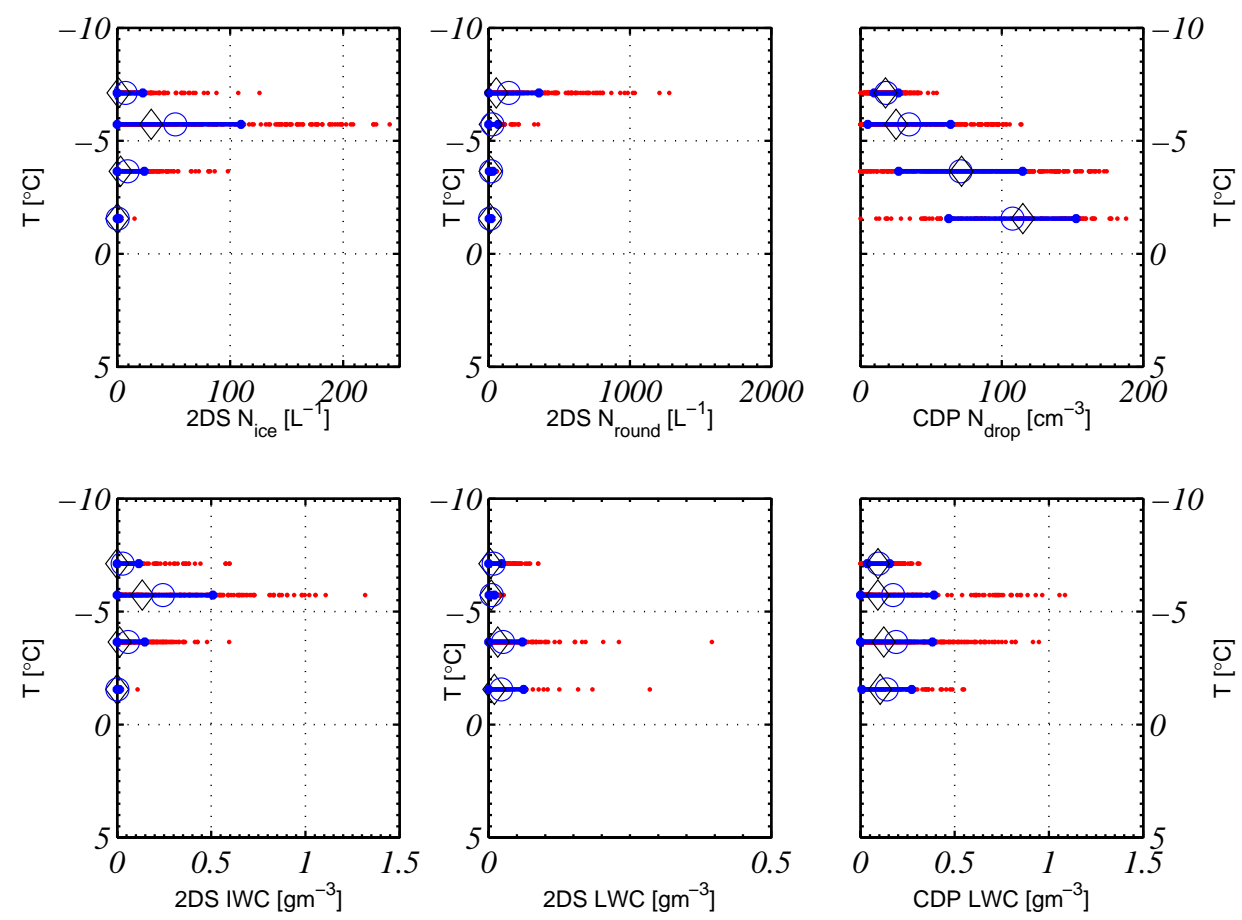

Fig. 3. In situ cloud particle number concentrations and ice and liquid water contents from flight B425, runs R1 to R7, as a function of ambient temperature. Red dots indicate a single $1 \mathrm{~Hz}$ data point; the black diamond is the median for the run and the large blue circle is the mean. The two smaller interconnected blue circles are one standard deviation from the mean.

velocities of between $1-2 \mathrm{~m} \mathrm{~s}^{-1}$, with associated peak liquid water contents of up to $1 \mathrm{~g} \mathrm{~m}^{-3}$ in the strongest updrafts. Rimed ice particles were also present in this region in concentrations of $1-10 \mathrm{~L}^{-1}$, and the radar echo here was around 15-20 dBZ. A further mixed phase region, quiescent in nature, consisting of rimed ice and small columns followed. Mixed phase conditions were then encountered at a distance of $18.3 \mathrm{~km}$ from CFARR and persisted for $5.3 \mathrm{~km}$ with peak ice crystal number concentrations of up to $80 \mathrm{~L}^{-1}$ and ice water contents of approximately $0.2 \mathrm{~g} \mathrm{~m}^{-3}$. Closer to CFARR, the cloud was mainly comprised of supercooled liquid with some drizzle drops present. 2DS imagery showed that there was no detectable ice present.

On the next in-cloud run (R4, outbound from CFARR, altitude $=1.93 \mathrm{~km}, T=-6^{\circ} \mathrm{C}$ ) at a distance of 13 to $20 \mathrm{~km}$ from CFARR, graupel and pristine column crystals were observed, the latter in concentrations of $100-200 \mathrm{~L}^{-1}$, with corresponding ice water contents of $0.5-1 \mathrm{~g} \mathrm{~m}^{-3}$. Low concentrations of supercooled droplets were also present (up to $25 \mathrm{~cm}^{-3}$ ). Heavy riming (and freezing of water within the ports) of the turbulence probe made subsequent wind measurements unreliable for the remainder of this run. $30 \mathrm{~km}$ from CFARR the droplet concentration increased to $50 \mathrm{~cm}^{-3}$ and continued to increase to around $100 \mathrm{~cm}^{-3}$ over the next $6 \mathrm{~km}$ while the ice crystal concentration reduced to zero.

A run was also performed close to cloud top (R5: $T=$ $-7.5^{\circ} \mathrm{C}$ ) at an altitude of $2.24 \mathrm{~km}$. A mixed phase feature
10.1 to $22.1 \mathrm{~km}$ from CFARR displayed typical ice concentrations of less than $20 \mathrm{~L}^{-1}$ with ice water contents less than $0.1 \mathrm{~g} \mathrm{~m}^{-3}$. A few small regions showed enhancements of ice concentrations exceeding $100 \mathrm{~L}^{-1}$ and ice water contents of $0.5 \mathrm{~g} \mathrm{~m}^{-3}$. The ice particles in these regions were of similar habit to those of previous runs. Within this run supercooled droplets were present at low concentrations $\left(10-30 \mathrm{~cm}^{-3}\right)$ and liquid water contents were typically in the range of $0.05-$ $0.2 \mathrm{~g} \mathrm{~m}^{-3}$.

Runs R6 and R7 were subsequently performed above cloud to assess potential seeding from above at altitudes of $2.54 \mathrm{~km}$ and $2.24 \mathrm{~km}$ respectively. However none of the cloud spectrometers detected any particles within their capabilities, thus making the possibility of ice seeding initiating glaciation in these clouds from an above cloud source unlikely. This is also supported by the radar scans and vertical profiles.

\subsection{In situ aerosol properties}

Aerosol measurements showed the operational area to be representative of clean air mass types. Below cloud base the mean PCASP aerosol number concentration was around $120 \mathrm{~cm}^{-3}$ (run R2, Altitude $=0.75 \mathrm{~km}$ ). A run above the inversion (R6, Altitude $=2.54 \mathrm{~km}$ ) found the aerosol number concentration was only $\sim 10 \mathrm{~cm}^{-3}$.

The sub-micron aerosol mass composition on average below cloud, as measured by the C-ToF-AMS, was: $0.28 \mu \mathrm{g}$ 

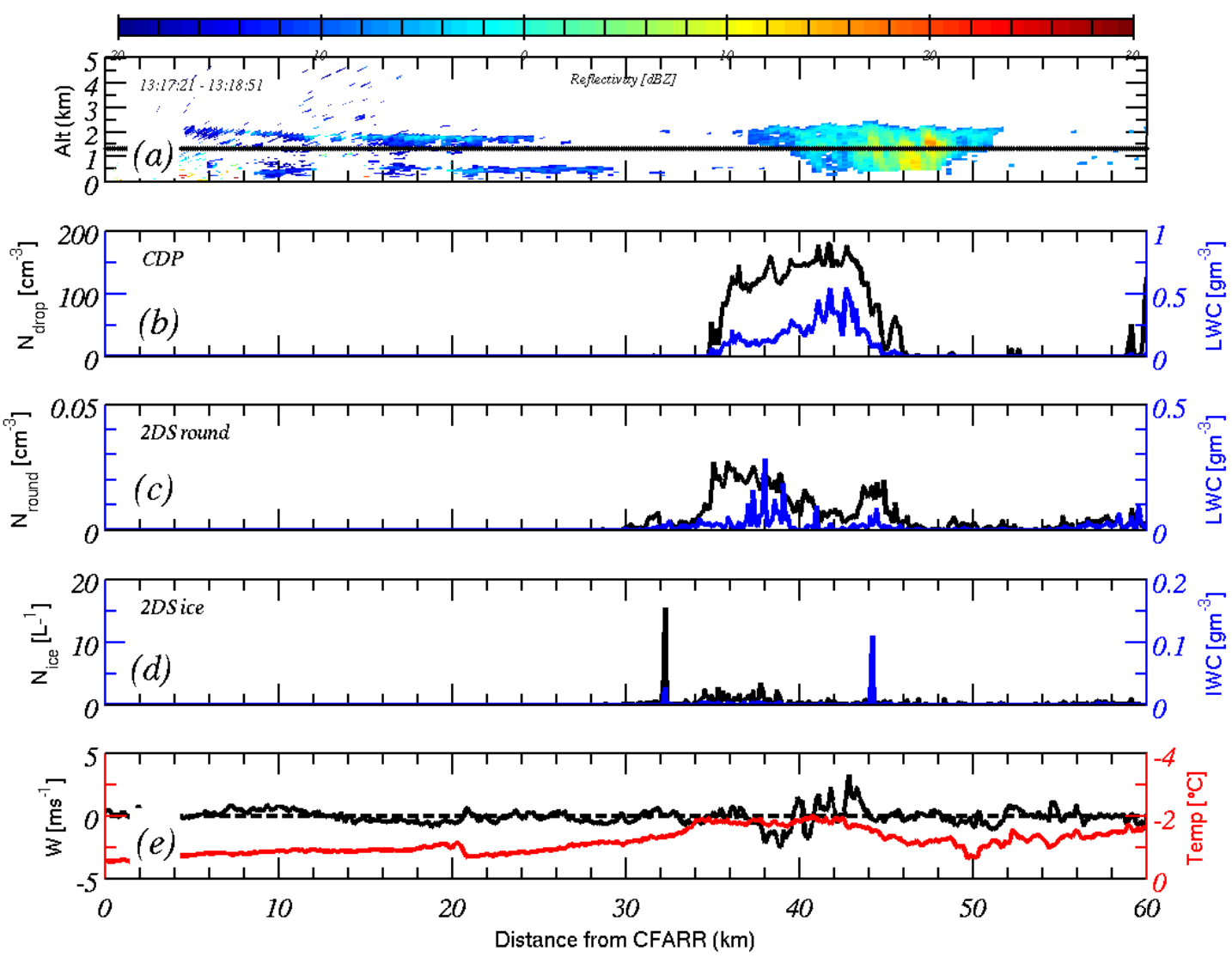

Fig. 4. Reflectivity from the $3 \mathrm{GHz}$ CAMRa RHI scan along the $253^{\circ}$ radial and GPS altitude (a) - (top panel, time of scan indicated in top left). In situ total particle number concentration (black lines, left axes) and mass loadings (blue lines, right axes) measured by the CDP (b) as a function of distance from CFARR; 2DS round classification (c), and 2DS ice classification (d). Also shown (e); in situ temperature from the de-iced Rosemount sensor; vertical wind speed from the 5-hole pressure port turbulence probe, all from run R1, inbound to CFARR.

$\mathrm{m}^{-3}$ of organic aerosol; $0.11 \mu \mathrm{g} \mathrm{m}{ }^{-3}$ of sulphate; and $\mathrm{NH}_{4}{ }^{+}$ and $\mathrm{NO}_{3}^{-}$each contributed approximately $0.05 \mu \mathrm{g} \mathrm{m}^{-3}$ to the total. For reference the total aerosol mass as determined with from the PCASP was $2.05 \mu \mathrm{g} \mathrm{m}^{-3}\left(\rho=1.4 \mathrm{~g} \mathrm{~cm}^{-3}\right)$. The relative aerosol composition breakdown observed during run R2 was very similar to that measured at the CFARR ground site (again with a C-ToF-AMS) during the first half of the flight. In each case, organic aerosol represented around 50\% of the total mass, sulphate contributed $25 \%$, nitrate $10 \%$, with varying contributions from other species. The organic mass spectra showed the same ordering of $\mathrm{m} / \mathrm{z}$ peaks in each case and indicated a mixture of combustion sources (solid fuel burning and vehicle emissions) together with a more atmospherically aged component.

The WIBS detected material consistent with primary fluorescent biological aerosol particles (PBAP), with modal diameters between $\sim 1.5 \mu \mathrm{m}$ to $2.5 \mu \mathrm{m}$. The potential for these particles to act as ice nuclei at slightly supercooled temperatures is discussed later. However, no PBAP measurements were made on the aircraft so no direct comparison is possible.
Comparison of the average aerosol size distribution measured throughout the duration of the flight at the ground site with those from the below cloud run on the aircraft, show similar concentrations across their overlapping size ranges for the SMPS and PCASP (Fig. 6a), suggesting that the air at the ground was coupled to and representative of the air just below the base of the cloud. This was confirmed by the Doppler cloud radar measurements which were limited to heights above $500 \mathrm{~m}$. Doppler velocity variances were used to determine the turbulence profile and estimate eddy dissipation rates using the technique described by Bouniol et al. (2003). Dissipation rates in excess of $10^{-4} \mathrm{~m}^{2} \mathrm{~s}^{-3}$ were observed at all levels through the cloud showing that mixing was occurring from cloud top down to near surface, hence aerosol properties should be similar.

Analysis of the nucleopore filters taken on the ground revealed that most of the detected particles had compositions and morphologies indicative of sea salt. After sea salt, the most frequently identified elements in these particles were $\mathrm{Fe}, \mathrm{Si}$ and $\mathrm{Al}$, which are found in abundance in mineral dusts. Those particles that were predominantly mineral dust 

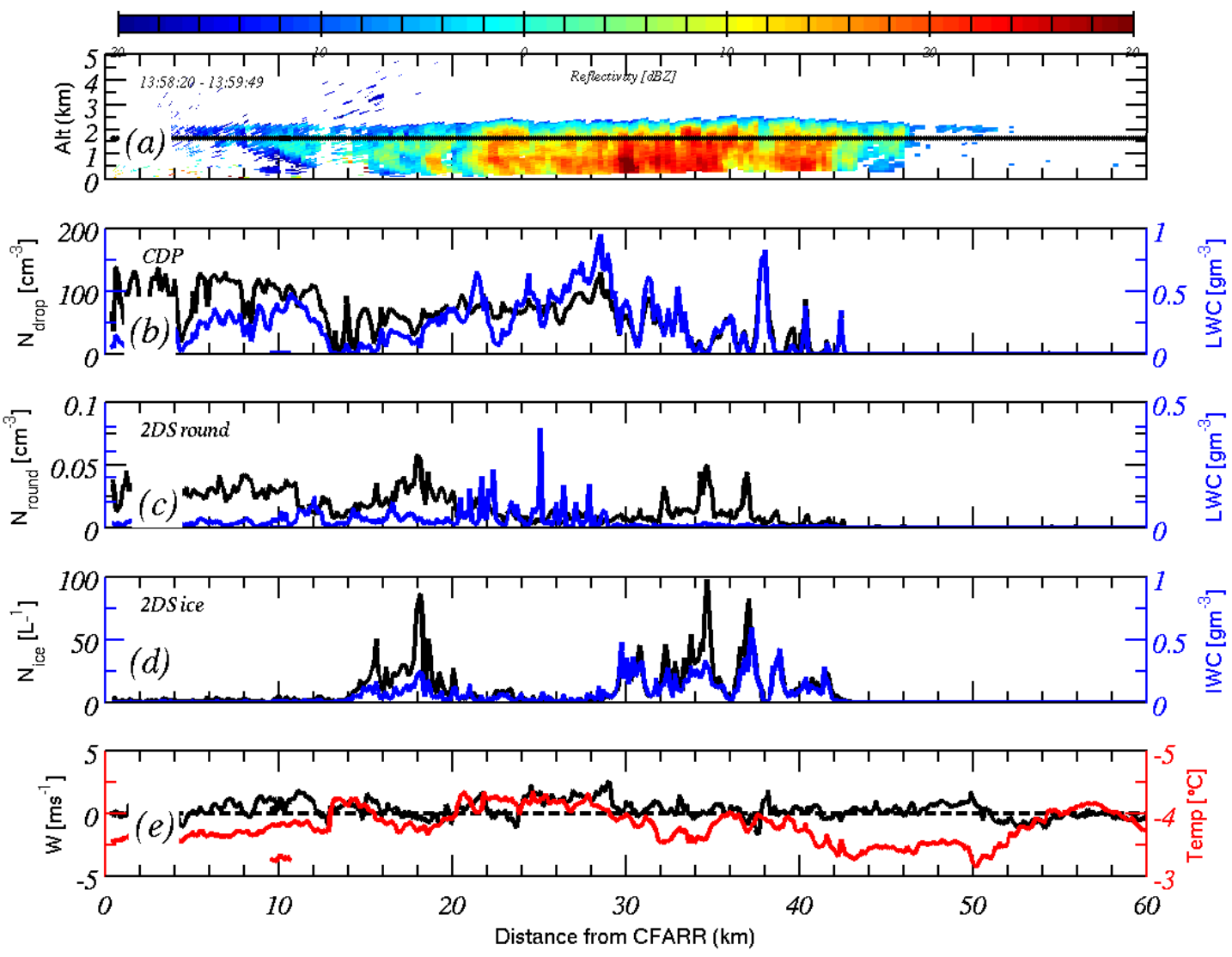

Fig. 5. Same as Fig. 4 but for Run R3, inbound to CFARR.

in composition had equivalent area diameters of up to $5 \mu \mathrm{m}$. Sea salt aerosols were found with diameters up to $10 \mu \mathrm{m}$.

The size distributions for all particles, and the fraction of those identified as mineral dust (from the SEM-EDX analysis) and biological particles (from the WIBS probe) are shown in Fig. 6a and c respectively. The lognormal fits to the size distribution data are also given in Fig. 6a, b.

Note that mineral dust was generally present for sizes larger than $0.6 \mu \mathrm{m}$ (Fig. 6c), while the dust fraction steadily decreased with size until $5 \mu \mathrm{m}$. The biological particles showed the opposite trend.

Further evidence that the aerosols measured at the ground were transported to the cloud base was found by applying the Aerosol-Cloud and Precipitation Interactions Model (ACPIM) in a parcel model configuration. ACPIM was initialised with the aerosol size distribution and chemical composition measured at the ground, and used to predict the number of $\mathrm{CCN}$ in the air just below cloud base for different updraft speeds, based on the aircraft in situ measured turbulence velocities (described below). C-ToF-AMS measurements showed the aerosols measured both at the ground and on the aircraft (during out of cloud runs) were dominated by organic material. A Positive Matrix Factorisation (PMF, Ulbrich et al., 2009; Lanz et al., 2007) analysis of the aerosol suggested that the composition breakdown of the organic components was approximately: $50 \%$ of biomass burning origin (BBOA); $33 \%$ hydrocarbon like organic aerosol (HOA) and $17 \%$ low-volatility oxygenated organic aerosol (LV-OOA). HTDMA data suggested that there were two modes of different hygroscopicity, implying some aerosol of different composition were externally mixed. It is likely that the BBOA would form one internal mode while the HOA and LV-OOA would be internally mixed with the ammonium sulphate and nitrate, which were present as 25 and $10 \%$ of the total (organic and inorganic) aerosol mass. In the absence of further information, Fulvic acid was used as the representative of both the biomass burning aerosol and the mixture of HOA and LV-OOA. To input the aerosol size distribution, 3 lognormal modes were fitted to the observed composite size distribution measured at the ground. Figure $6 a, b$ show the observed data, plus the log normal fits. The lognormal fit parameters are provided in the caption.

Sensitivity studies were undertaken to try to ascertain the importance of aerosol composition to the $\mathrm{CCN}$ activity. Five scenarios were examined: (i) for a composition of pure ammonium sulphate; (ii) for a composition of pure fulvic acid; (iii) for an internal mixture comprised of ammonium sulphate ( $25 \%$ by mass); ammonium nitrate ( $10 \%$ by mass) and 

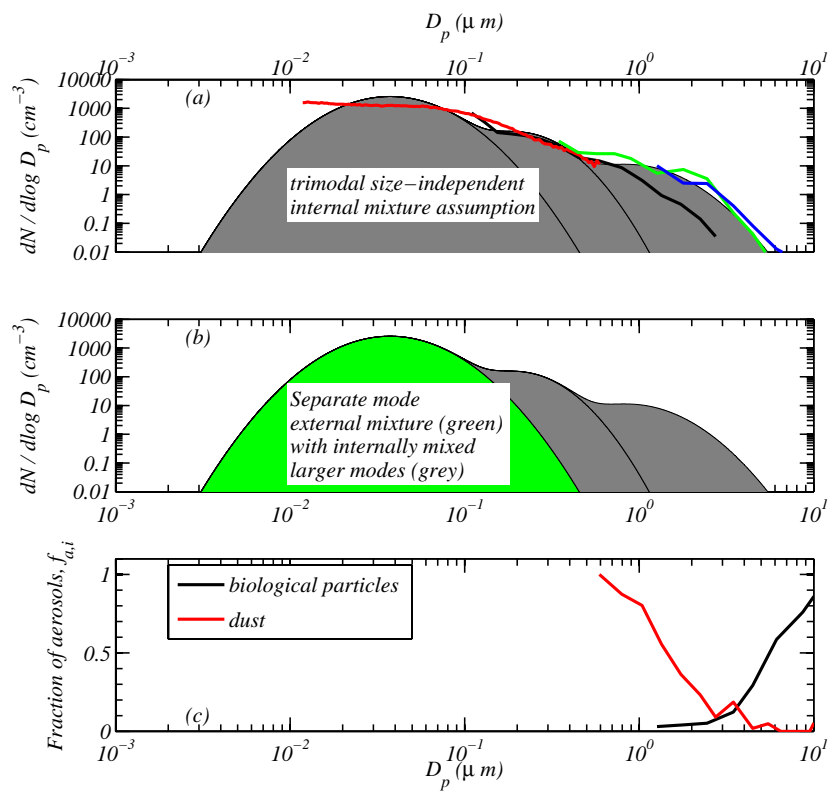

Fig. 6. (a) the ground based and aircraft (run R2, below cloud) aerosol size distribution measurements. Red line: SMPS (ground); Black line: PCASP (aircraft); Green line: GRIMM (ground); Blue line: WIBS total (ground). Note that in some of the ACPIM runs we assumed that the aerosols had size independent composition (as shown in a) and in other runs that the aerosol had a small mode of non-hygroscopic organic aerosols (as shown in b). (c) the fraction of aerosols measured by the WIBS and determined to be of biological origin (black line), and the fraction of the filter sample derived aerosol size distribution (determined from ESEM/EDX analysis of samples) that was refractory in nature (red line). The three lognormal modes that were fitted to the data have fit parameters: $n=[3221,145,13.7] \mathrm{cm}^{-3} ; \bar{d}=[37,200,861] \mathrm{nm}$ and $\ln \sigma_{g}=[0.50,0.40,0.49]$.

Fulvic acid ( $65 \%$ by mass); (iv) for a case consisting of an external mixture of three compositional modes (ammonium sulphate, ammonium nitrate and fulvic acid) with mass ratios of all three that are independent of size and equal to that of case (iii); lastly (v) for a case where the two larger size modes were comprised of an internal mixture of all 3 components as in case (iv) but with the smallest mode comprised of purely fulvic acid. The last case is likely to be the most realistic based on the arguments that the biomass burning organic aerosol is likely to be externally mixed from the rest of the aerosol.

The model was run for 9 different constant updraft speeds $\left(0.01,0.03,0.05,0.1,0.2,0.5,1.0,2.0\right.$ and $\left.2.5 \mathrm{~m} \mathrm{~s}^{-1}\right)$, starting at $950 \mathrm{mbar}$ and $+1{ }^{\circ} \mathrm{C}$ at an $\mathrm{RH}$ of $95 \%$, and in each case, ascents of $400 \mathrm{~m}$ were undertaken. No ice phase processes were switched on in these simulations as they were primarily to test the description of the aerosol activation process within the model, while using as much ground based data as was possible.
From the model output the maximum super saturation attained against the number of particles that were activated above cloud base is plotted for each of the five composition cases (Fig. 7a). Data from a dual column CCN instrument during the below cloud run R2 (at $750 \mathrm{~m}$ altitude), were used for comparison with these data. At the two supersaturations used $(0.08$ and $0.12 \%)$, the average $\mathrm{CCN}$ concentrations were 30 and $54 \mathrm{~cm}^{-3}$ respectively. These two data points are shown plotted together with the model simulations in Fig. 7a. This shows that the best agreement between model and data was found when assuming an external mixture. For this case there is no significant difference between assuming aerosol are all internally mixed or that they exist as an external mixture, however, the presence of the organic component was important in reducing the overall $\mathrm{CCN}$ activity. Note that case (v) which considers a separate mode of small organic aerosol shows a relative insensitivity to updraft speed in the range $w=0.5 \rightarrow 2.5 \mathrm{~m} \mathrm{~s}^{-1}$. Because of this assumption case (v) later turns out to be the best assumption to adopt (see Section 5.2)

Probability density analysis of the aircraft measured $32 \mathrm{~Hz}$ vertical wind speeds in-cloud through run R1 yielded a modal value of $0.6 \mathrm{~m} \mathrm{~s}^{-1}$. For the first four assumptions of aerosol mixing state (except case (ii)), this relates to an activated droplet number concentration of approximately $350 \mathrm{~cm}^{-3}$ for the ACPIM parcel model, significantly higher than the observations of droplet number concentration which peaks at $\sim 150 \mathrm{~cm}^{-3}$ (Fig. 3). In the same regions the liquid water content was found to be close to adiabatic with $1 \mathrm{~g} \mathrm{~m}^{-3}$ at $-5^{\circ} \mathrm{C}$ (with cloud base at $0^{\circ} \mathrm{C}$ ). Only the run that assumes that the smallest mode is an externally mixed organic aerosol is able to predict $\sim 150-180 \mathrm{~cm}^{-3}$ of cloud drops for the above updraft speed.

A further possibility to explain the difference between the measured drop concentration and the predicted drop concentration for composition assumptions (i) to (iv) is that there is dilution of the air as it ascends through the atmosphere. The radiosonde temperature sounding from nearby Larkhill (Fig. $8 \mathrm{c})$ showed a slight inversion $(\sim 0.2$ to 0.3 degrees in potential temperature) at $\sim 1 \mathrm{~km}$, just below cloud base, for this case study; note that this inversion is not present in the WRF simulation (described below) as WRF was run from a global meteorological analysis, which tends to smooth out such gradients. The effect of turbulent mixing between the boundary layer and free tropospheric air at this inversion would be to reduce concentrations of aerosols surviving into cloud base, which assuming aerosol composition assumption (v) to be correct would lead to an under-prediction in cloud droplet number. However, it should be noted that it cannot be ruled out that a combination of some turbulent loss across the inversion at cloud base and an aerosol composition assumption somewhat between options (iv) and (v) could exist which would also lead to the observed droplet number concentrations. However the exact reason for the observed drop numbers is not crucial to the remaining analyses. 

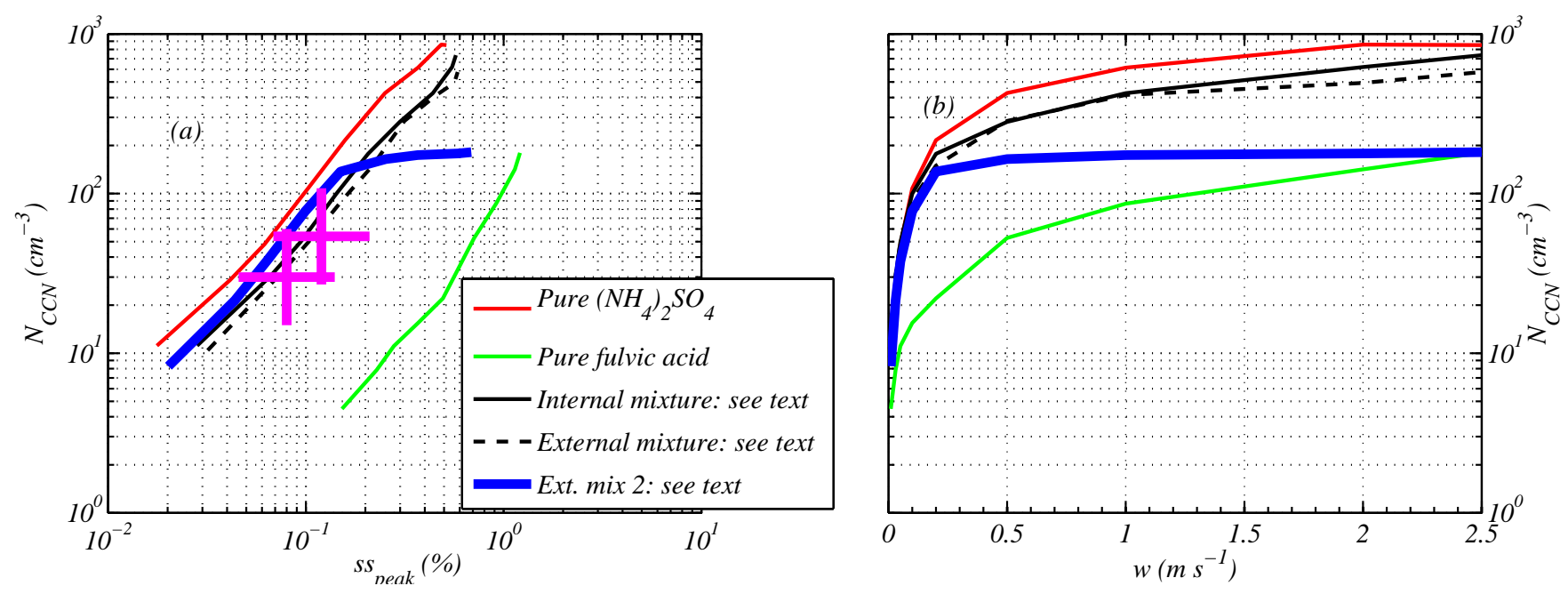

Fig. 7. (a) The results of parcel model simulations predicting the CCN concentration for different prescribed up-draught speeds plotted against the peak super-saturation attained, for different assumptions regarding mixed aerosol composition (see text). Also shown on the same plot are the measured CCN concentrations at super-saturations of 0.08 and $0.12 \%$ in the air below cloud base (from aircraft run R2 below cloud base); (b) the modelled $\mathrm{CCN}$ concentrations plotted against updraft speed for the same cases. The Pure $\left(\mathrm{NH}_{4}\right)_{2} \mathrm{SO}_{4}, \mathrm{Pure} \mathrm{fulvic}$ acid and Internal mixture cases correspond to runs that assume a constant composition across the whole size distribution (see Fig. 6a for a schematic); the External mixture case corresponds to an external mixture of three pure components, that have equal number ratios across the whole distribution (see text); and the Ext. mix 2 case refers to an assumption where the smallest mode has a composition that is a nonhygroscopic organic acid with the other modes set to an internal mixture as described in the text (see Fig. $6 \mathrm{~b}$ for a schematic). The effect that this latter assumption has is to limit the maximum number activated to approximately $180 \mathrm{~cm}^{-3}$ for updrafts larger than $\sim 0.5 \mathrm{~m} \mathrm{~s}$.

As indicated previously, CAMRa observed a layer of weak reflectivity (in the cloud free region) in the nearest $30 \mathrm{~km}$ to CFARR at the time of R1 (Fig. 4). This was identified as being an echo from the base of the inversion, caused by the turbulent mixing of the dry air from the free troposphere with the moister air in the boundary layer (e.g. Morcrette et al., 2007) and so is consistent with the above hypothesis of aerosol loss across this layer.

In summary, the aerosols measured at the ground are strongly linked to the aerosols at $750 \mathrm{~m}$, but in order to explain the number of drops activated in the cloud either of the following may be true:

- The small aerosols are comprised predominantly of organic components and so are less hygroscopic than the rest of the size distribution as simulated in case (v) above.

- The slight inversion just below cloud base results in reduced aerosol concentrations interacting with the cloud via entrainment.

\section{Modelling results}

\subsection{Sensitivity studies of the HM process using WRF}

Using the set-up described in Sect. 3.1, an initial $24 \mathrm{~h}$ simulation was performed with WRF, using the Morrison mi- crophysics scheme and a fixed droplet number concentration of $150 \mathrm{~cm}^{-3}$ based on the peak concentration from the in situ measurements. To help assess the performance of the model, the simulated reflectivity was calculated at the gridpoint closest to CFARR $\left(51.15^{\circ} \mathrm{N}, 1.45^{\circ} \mathrm{W}\right)$ within the innermost domain, to allow for comparison with the reflectivity time series as measured by the vertically pointing radar. The simulated reflectivity was diagnosed from the 6th moment of the size distribution for precipitation-sized particles (i.e. rain, snow and graupel).

Comparison of the simulated reflectivity timeseries with that observed showed (not shown here) that the timing of the rain bands associated with the passing of the fronts during the night and into the morning were well simulated by the model. The most interesting aspect of the simulation was the presence of a strong reflectivity signature at around 14:30 UTC, which is consistent with the onset of convection over CFARR. Although the timing of convection over the Chilbolton region was captured by the model, the simulated cloud top was slightly higher. This can be explained through analysis of model temperature profiles vs. radiosonde data for selected locations at 12:00 UTC. This shows that the model was not able to capture the sharp inversion at around $2 \mathrm{~km}$ which was clearly present in the radiosonde profiles (Fig. 8). This failure is likely due to insufficient vertical resolution in the model and/or analyses used for initialisation.

Further analysis of the model fields also revealed some differences in the history of the convective cloud system. 

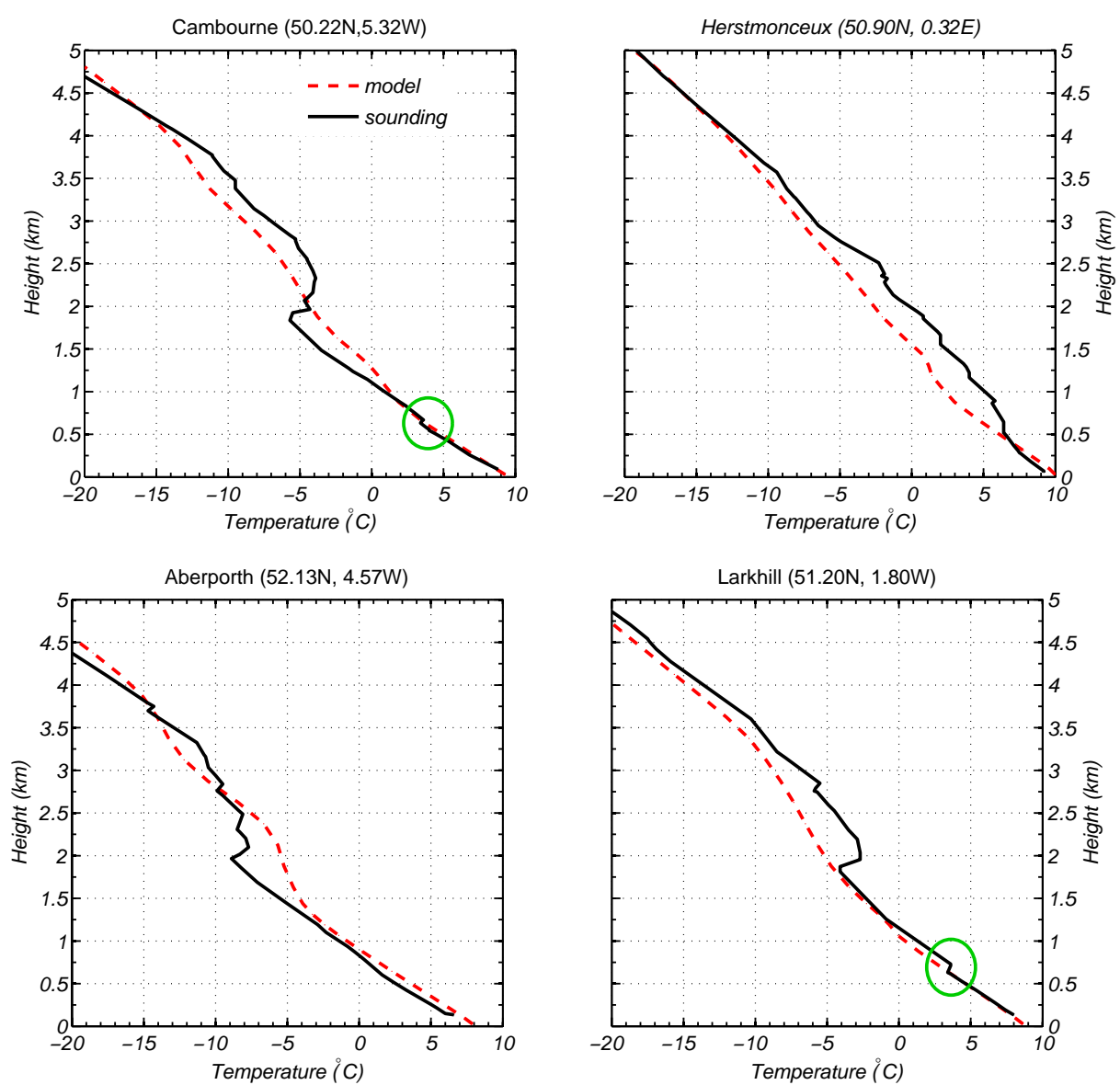

Fig. 8. Temperature profiles from radiosonde data (black) and the WRF model simulation (red) at selected locations. All profiles are taken at 12:00 UTC on the 22 January 2009 . Note the small inversion just below cloud base at $\sim 750 \mathrm{~m}$ in the Larkhill and Cambourne soundings (green circle).

In the simulation, the origin of the convective activity was traced back to the Devon and Cornwall peninsula around late morning, which then advected eastwards where it reached the Chilbolton region at around 14:30 UTC. This is in contrast to the rainfall radar observations, which suggest a later spinup. Meridional cross-sections through the simulated cloud taken at a latitude $51^{\circ} \mathrm{N}$ at 12:00 UTC (Fig. 9) reveal the mixed-phase nature of the cloud and that it is also producing precipitation at this time. The warm rain process (represented through the autoconversion scheme of Khairoutdinov and Kogan, 2000) does contribute to precipitation formation here, although a significant amount of precipitation also develops via growth of ice by deposition and/or collection of cloud droplets, forming snow and graupel which then melts to form rain below cloud base $(\sim 1 \mathrm{~km})$. Note the role of rain in the HM process is explored in more detail with the ACPIM model in Sect. 5.2

In the Morrison scheme, the $\mathrm{HM}$ process can activate in the temperature range between $-3^{\circ} \mathrm{C}$ and $-8^{\circ} \mathrm{C}$, but depends on the mass of supercooled liquid (both cloud liquid water and rain) available for riming. Rime splintering acts to increase both the mass and number of the cloud ice category, and can act on both snow and graupel depending on which categories are present. Growth of snow through riming of cloud water converts it to graupel, independent of the HM process.

An additional simulation was performed where the HM process was switched off from the start of the run (00:00 UTC, 22 January 2009) and the results were compared directly to the simulation where HM was included. Figure 10 (left and centre panels) shows that, by 12:00 UTC, a considerable reduction is noticeable in both cloud ice and snow number concentrations due to the effect of switching off the HM process (as noted in the difference plots on the bottom row).

In particular, the cloud ice number concentration reduces from peak values of $\sim 30 \mathrm{~L}^{-1}$ to less than $\sim 1 \mathrm{~L}^{-1}$ whereas the snow number concentration reduces from peak values of $\sim 15 \mathrm{~L}^{-1}$ to less than $\sim 2 \mathrm{~L}^{-1}$. Figure 10 (right panels) shows the effect HM has on the graupel number concentration. The graupel number concentrations, even in the absence of HM, still reach up to $\sim 5 \mathrm{~L}^{-1}$ at 12:00 UTC. The impact on 
precipitation at 14:30 UTC is shown in Fig. 11. Switching off HM leads to a reduction in the spatial extent of the precipitation produced; however, there is no significant reduction in the maximum intensity and therefore the HM process does not appear to be critical to the production of precipitation in this particular simulation. This suggests that even in the absence of HM the graupel number concentrations are high enough to sustain the precipitation.

Additional simulations (not shown) revealed that disabling the graupel category, such that the solid phase is represented by simply cloud ice and snow, results in an increase in snow mass due to conservation of total water. However there is a shift in the size distribution towards larger, fewer snowflakes $\left(\sim 1 \mathrm{~L}^{-1}\right)$ due to aggregation (the lack of a self-collection term for graupel explains the higher number concentrations when graupel is included). The impact of this change in size and habit of ice crystals on surface precipitation was small, suggesting that the simulated shallow convective cloud is largely insensitive to the categorisation of ice. A further test with all ice processes switched off resulted in considerably reduced precipitation, and most notably a distinct lack of precipitation over the Chilbolton area by 14:30 UTC. Thus it can be concluded that the WRF simulation cannot sustain precipitation via the liquid phase alone; for this a consideration of the ice phase is also necessary. In this particular case the HM process was not found to be critical in order to maintain precipitation, implying that sufficient ice was produced through the parameterisation of primary nucleation. This is in contrast to the results from the detailed ACPIM modelling (which follow in Sect. 5.2), which show that the warm rain process was key to production of precipitation.

Primary ice nucleation in the version of the Morrison scheme used in this study includes two mechanisms. The first of these is based on the parameterization of Cooper (1986), and is permitted to occur at all temperatures colder than $-8^{\circ} \mathrm{C}$, if the supersaturation with respect to ice exceeds $8 \%$. The concentration of ice crystals predicted by this parameterization is limited to a maximum value of $500 \mathrm{~L}^{-1}$ to prevent unrealistically high concentrations at lower temperatures. If the predicted concentration of new ice crystals from the Cooper scheme is less than the concentration of ice particles already present, no additional ice particles are allowed to form via this scheme.

Based on the coldest cloud top temperature in the model simulation $\left(-14^{\circ} \mathrm{C}\right)$, the ice crystal concentration predicted by the Cooper (1986) parameterization is $0.35 \mathrm{~L}^{-1}$. This is approximately 6 times larger than the concentration predicted using the observed aerosol data (Fig. 6a) in the DeMott et al. (2010) parameterisation for the observed cloud top temperature $\left(\sim-8^{\circ} \mathrm{C}\right)$.

The second mechanism by which primary ice can form in the scheme, is based on the freezing of supercooled liquid, with separate treatments for cloud liquid droplets and rain. The freezing parameterizations are allowed to contribute if the temperature is below $-4{ }^{\circ} \mathrm{C}$ and if there is liquid wa- ter and/or rain present. The mass and number of raindrops that freeze is then determined from the parameterization of immersion freezing (from Bigg, 1953). In the case of cloud droplets, freezing can also occur due to contact freezing (where the number of contact IN is obtained from Meyers et al., 1992), in addition to immersion freezing. The stochastic nature of both the contact and immersion freezing parameterizations means that they operate independently of the existing total ice crystal concentration, and are limited only by the number concentration of liquid drops available. Thus new ice crystals can continue to be produced by the model so long as there is supercooled liquid present and the temperature is cold enough.

Repeated simulations were performed with the model to isolate the contribution from each primary ice nucleation scheme to the total ice crystal concentration and the subsequent impact on precipitation. This was done by switching off each nucleation scheme in turn to isolate the effect of the other (note that freezing of droplets is treated as a single mechanism from the combined effect of both contact freezing and immersion freezing schemes together). The HM process was left switched off for these simulations to focus purely on primary ice.

Additional diagnostics were also output from the model every 15 minutes, to quantify the instantaneous ice number concentration tendency from both the Cooper scheme and drop freezing schemes respectively. Here, tendency is defined as the contribution of a particular process to the change in the given prognostic variable within a time step.

It was found that the model tended to produce most of the ice near to cloud top which then quickly grew to form snow (and subsequently graupel) which were then removed by sedimentation. Analysis of the ice crystal concentration tendencies revealed that fresh ice crystals were being formed at each timestep because the model does not account for the depletion of IN. Competition between the different pathways of ice nucleation was also noted, such that switching off one nucleation mechanism was compensated by an increase in the other.

A significant fraction of the simulated shallow convective cloud exhibited temperatures below $-10^{\circ} \mathrm{C}$ at cloud top, with some localised turrets reaching $-14^{\circ} \mathrm{C}$, which is significantly colder than that inferred from MODIS (Moderate Resolution Imaging Spectroradiometer) satellite retrievals concurrent with the sampling period, CFARR radar and aircraft observations at cloud top. The inability to account for the depletion of IN, coupled with the fact that cloud top is colder in the model than in reality, means the simulation produces too much primary ice. These deficiencies in the simulation negate the influence of the H-M process somewhat in terms of the impact on the precipitation rates, and highlight the difficulties associated with the representation of shallow convection in current mesoscale models. 

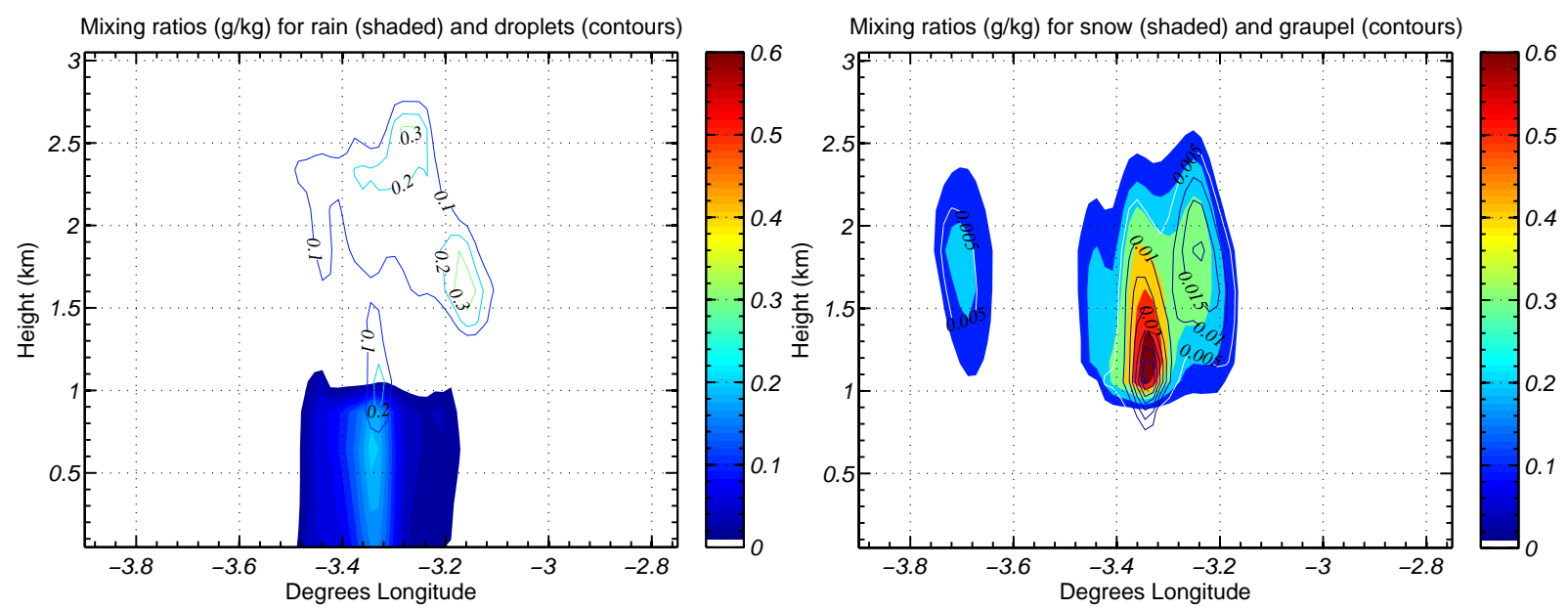

Fig. 9. Meridional cross-sections from model output at $51^{\circ} \mathrm{N}$ at time 12:00 UTC. Left: liquid mixing ratios (rain and droplet categories); right : ice mixing ratios (snow and graupel categories). Plots are in units of $\mathrm{g} \mathrm{kg}^{-1}$.

\subsection{Sensitivity studies of the HM process using ACPIM}

Results from ACPIM model runs will now be presented to aid a discussion and interpretation of the microphysical processes occurring within the observed cloud, before providing a summary of all the simulations. The ACPIM was run as a parcel model as described in Sect. 3.2 although in these simulations the ice processes were switched on. The parcel was set to rise through the atmosphere with an updraft speed of $0.5 \mathrm{~m} \mathrm{~s}^{-1}$ until it reached a temperature of $-5^{\circ} \mathrm{C}$ where it came to rest and remained there so that the cloud could develop microphysically. Four sets of simulations were carried out and compared. The simulations together with the rationale for carrying them out are listed below:

- Simulations examining sensitivity to aerosol number, including a "control" run which assumed the distribution shown in Fig. 6b and a low aerosol run which assumed the same distribution, but reduced by a factor of 1.5 in number. These runs used the Hall (1980) collision kernel and are referred to as "Aerosol number" sensitivity.

- Simulations as above but comparing the difference between the Hall (1980) kernel and the kernel enhanced by turbulence (Pinsky et al., 1999). Referred to as 'Kernel sensitivity'.

- Simulations assuming all of the aerosol were equally internally mixed across all size bins, with both the Hall (1980) and Pinsky et al. (1999) kernels. Referred to as "Composition sensitivity".

- Simulations with 3 different values of primary ice nuclei concentrations $(1 \times, 10 \times$ and $100 \times$ the DeMott et al., 2010, scheme). Referred to as "IN sensitivity".

These results will now be described.

\subsubsection{Aerosol number sensitivity}

Figure 12 shows a comparison between ACPIM simulations using the control aerosol size and composition distribution and the "low aerosol" run where the same aerosol number parameter in the lognormal fits was divided by 1.5 . The runs highlight the strong non-linearity that exists between the number of aerosol particles and the glaciation of the cloud.

Figure 12a shows the number of activated cloud drops in both cases. Unsurprisingly the run with low aerosol concentrations has the lower cloud droplet number concentration $\left(\sim 100 \mathrm{~cm}^{-3}\right.$ vs. $\left.\sim 180 \mathrm{~cm}^{-3}\right)$. In the run with higher aerosol concentrations the cloud droplet number remains almost constant for the whole of the run, whereas in the low aerosol run the cloud droplet number concentration reduces somewhat, due to collision and coalescence (and also capture by ice crystals), before the drops completely evaporate due to the Bergeron-Findeison process.

Figure $12 \mathrm{~b}$ shows the ice crystal number concentration in these two runs and reveals that in the control run with higher aerosol concentrations the ice particle concentrations are equal to the primary ice concentration $\left(1 \times 10^{-2} \mathrm{~L}^{-1}\right)$, whereas in the run with lower aerosol concentrations there is an explosive increase in the ice crystal concentration at about 80 min into the model run. The sharp increase in ice crystal number concentrations is preceded by an active warm rain process (see Fig. 12c) and this significantly affects the liquid water in the cloud (Fig. 12c inset). Eventually the cloud completely glaciates, leaving no liquid water in the cloud (it is all in the ice phase).

\subsubsection{Kernel sensitivity}

Figure 13 shows a comparison between ACPIM simulations using the Hall (1980) kernel and another run where the effect of turbulent enhancement of the collision kernel (following 

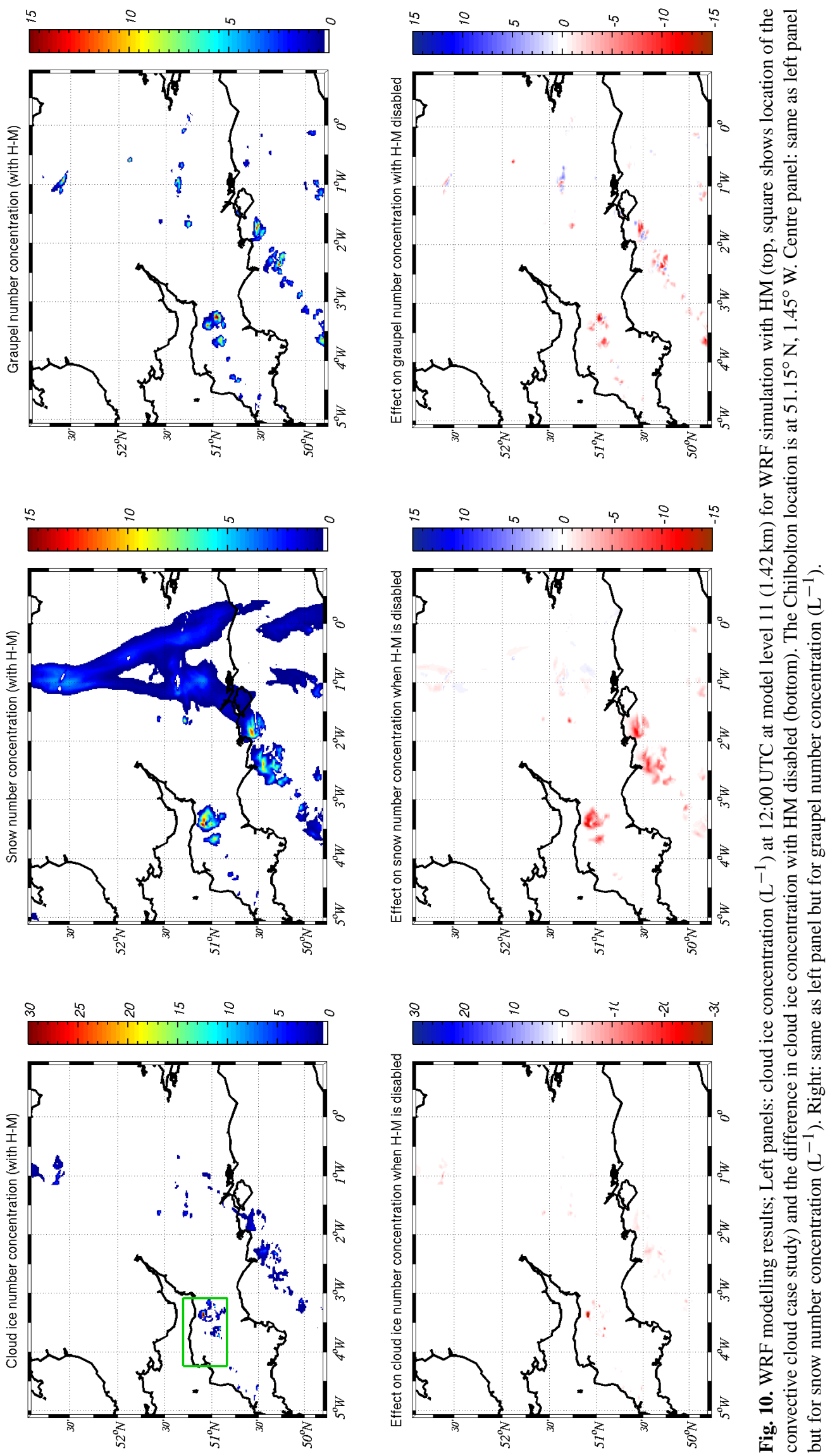

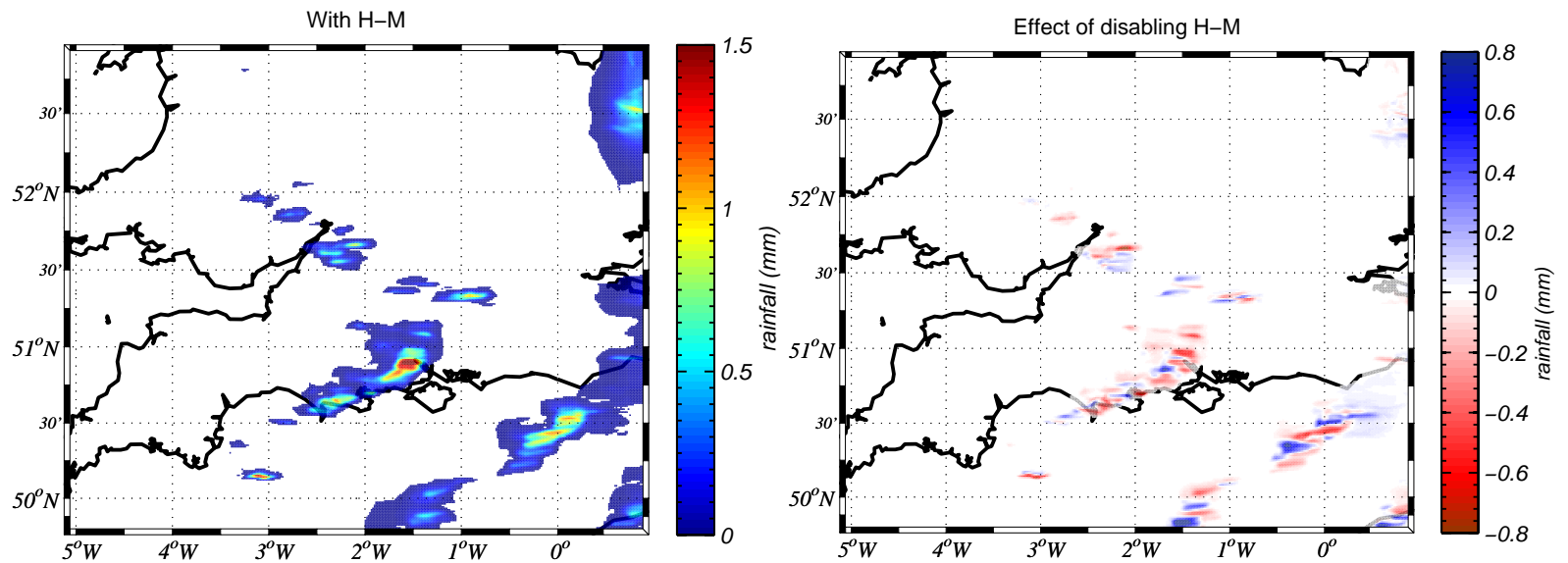

Fig. 11. Surface precipitation accumulated between 14:10 UTC and 14:30 UTC for: WRF with HM (left); Difference caused by disabling HM (right).
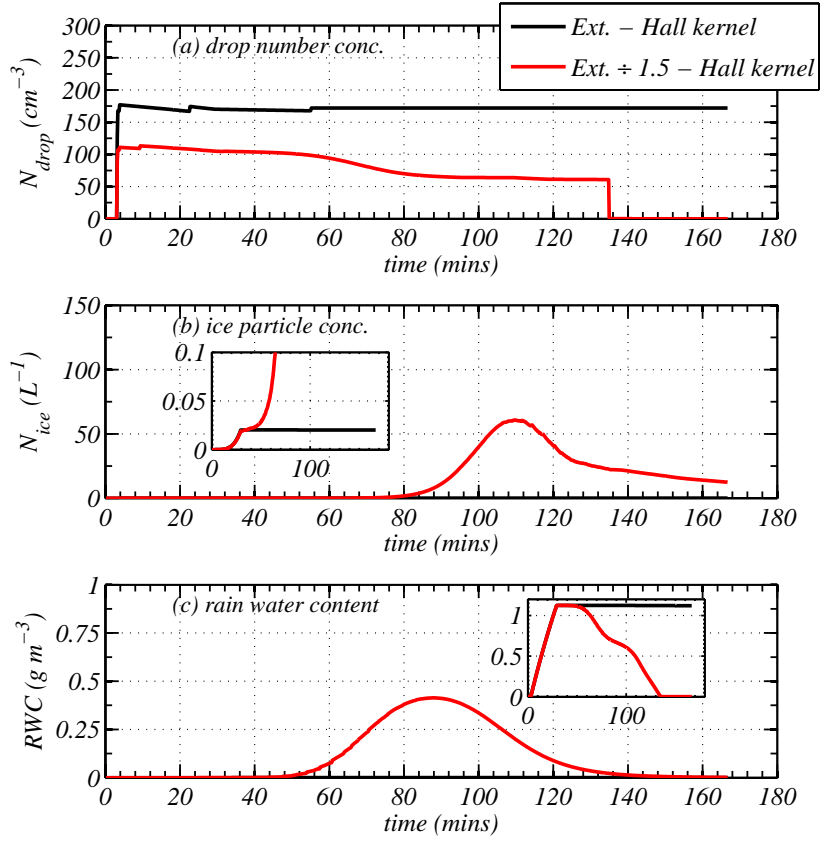

Fig. 12. Time series plots summarising the results from the ACPIM run using the input aerosol distribution assuming external mixture 2 (see text and Fig. 6b) - black lines - and the same distribution but with concentrations reduced by a factor of 1.5 (red lines) - both using collection kernel of Hall (1980). (a) number of activated cloud drops; (b) ice particle number concentration (inset is expanded to show lower scale); (c) rain water content (inset is the cloud water content). Note water is categorised as rain if the size is greater than $80 \mu \mathrm{m}$ diameter.

Pinsky et al., 1999) is used. The runs highlight the importance of broadening the cloud water size distribution and the onset of the warm rain process to the glaciation of the cloud.

Figure 13a shows the number of activated cloud drops in both cases. Initially both runs have the same number of cloud
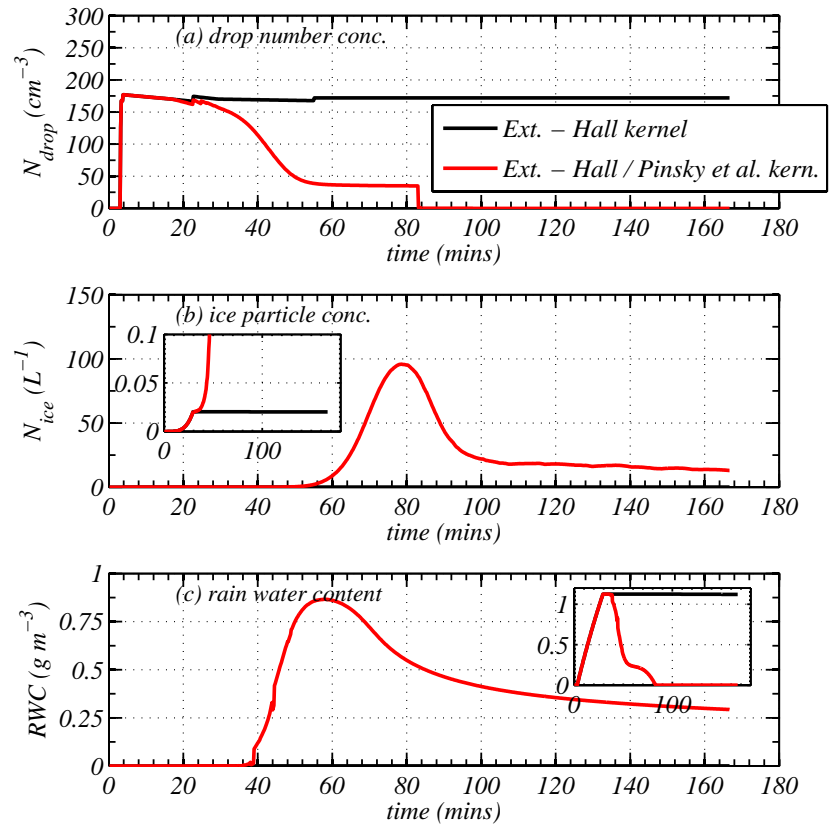

Fig. 13. As Fig. 12, except black lines correspond to a run with the Hall (1980) collision kernel and the red lines correspond to a run using a turbulence enhanced collision kernel after Pinsky et al. (1999). Note that enhancement of the collision efficiency of drops by turbulence significantly enhances the collision-coalescence process, which has a marked effect on the Hallett-Mossop process.

drops in them. However, the effect of turbulent enhancement of the collision kernel on the formation of warm rain is very pronounced and quickly reduces the number of cloud drops by collision-coalescence. The cloud drop concentration reduces to less than $50 \mathrm{~cm}^{-3}$ before they completely evaporate due to the Bergeron-Findeison process. 

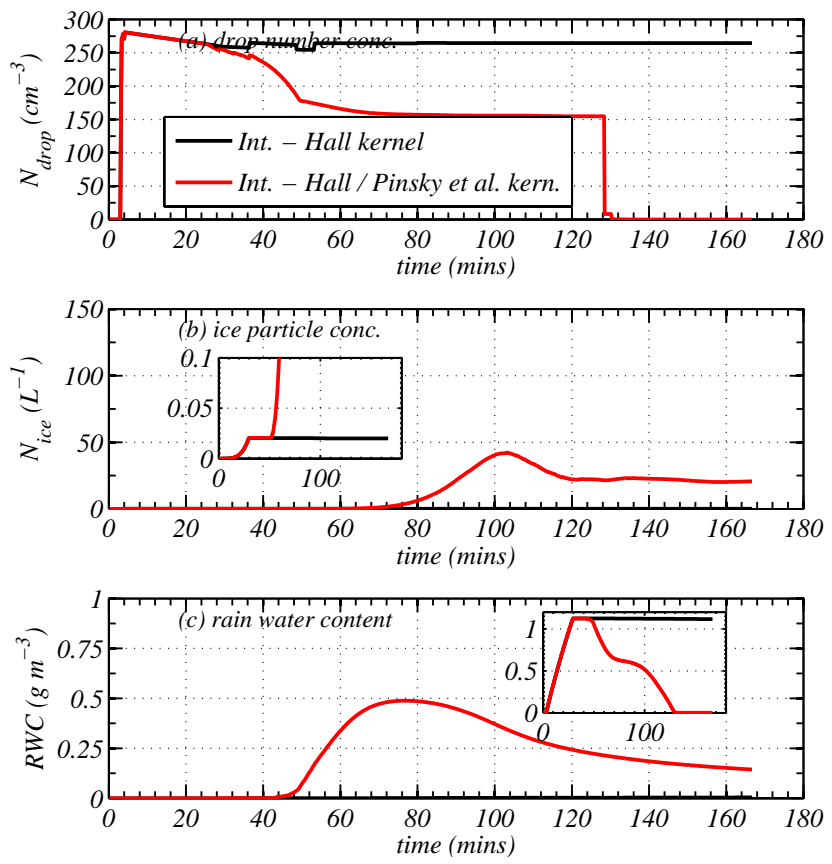

Fig. 14. As Fig. 12, except black lines correspond to a run with the Internal mixture assumption (see schematic in Fig. 6a and text) and the Hall (1980) collision kernel and the red lines are the same but with the collision kernel enhanced by turbulence (following Pinsky et al., 1999). The Pinsky et al. (1999) kernel results in a reduction of the drop concentration commensurate to what was measured by the aircraft (Fig. 3) this is followed by rapid ice multiplication.

Figure $13 \mathrm{~b}$ shows the ice crystal number concentration in these two runs and the result is similar to the "Aerosol number" sensitivity in that warm rain results in rapid glaciation.

Interestingly the run with the turbulent enhancement of the collision kernel does not completely glaciate as it still contains reasonably high rain water contents $\left(0.25 \mathrm{~g} \mathrm{~m}^{-3}\right)$ towards the end of the simulation (Fig. 13c) although the cloud water is reduced to zero (inset).

\subsubsection{Composition sensitivity}

Figure 14 shows a comparison between ACPIM simulations using the Hall (1980) kernel and another run using the turbulence enhanced collision kernel (following Pinsky et al., 1999), but also assumed that the aerosol had an internally mixed composition that was size-independent (see Sect. 3.2 and Fig. 7). The runs show that even though too many cloud drops are initially activated with these assumptions (when compared to the observed cloud drop numbers, Fig. 3) the collision-coalescence process may reduce the cloud drop number concentration to values that are in agreement with the aircraft measurements.

Figure 14a shows that when we assume the Pinsky et al. (1999) kernel the cloud droplet number concentration is reduced to around $150 \mathrm{~cm}^{-3}$, which gives good agreement with
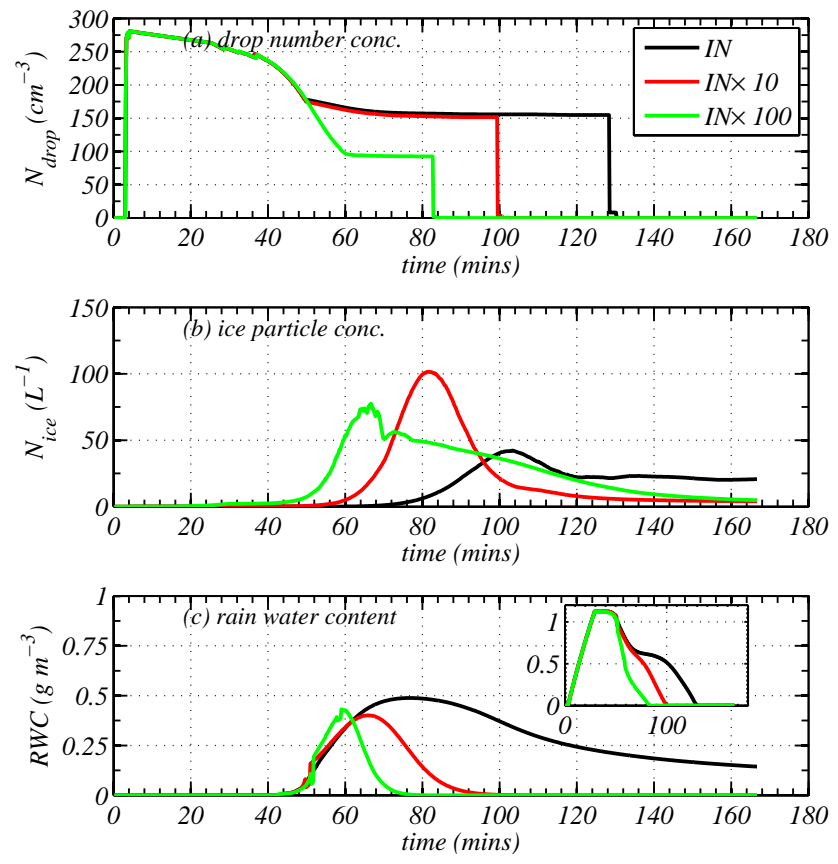

Fig. 15. As Fig. 12, except the three runs correspond to different numbers of primary IN (i.e. DeMott et al. $\times 1,10$ and 100). It can be seen that in all cases similar amounts of ice are eventually produced in the cloud.

the observations. This case also demonstrates an active warm rain process (Fig. 14c) and so enables an active HM process (Fig. 14b) leading to partial glaciation of the cloud by the end of the simulation.

\subsubsection{IN sensitivity}

Figure 15 shows a comparison between ACPIM simulations where the number of primary IN was varied by multiplying the DeMott et al. (2010) scheme by 1, 10 and 100. The runs demonstrate the non-linearity that primary ice number concentrations have on the number of ice crystals in this small cumulus cloud. All runs used the Pinsky et al. (1999) collision kernel.

Figure 15a shows that the initial cloud droplet number concentrations are the same in each case (as expected) and then quickly reduce due to collision and coalescence, which results in a reduction in cloud water (Fig. 15c, inset) and an increase in the rain water content (Fig. 15c, main panel). The runs glaciate over different time-scales resulting in cloud drops evaporating at different times in Fig. 15a. This has an interesting effect on the number of ice particles in the cloud (Fig. 15b). The run with medium IN concentrations $(10 \times$ the DeMott scheme) ends up with the highest peak concentration, but the lowest final concentration of ice particles.

Both the medium and the high IN concentration runs completely glaciate, with no liquid or rain water left in the cloud 
by the end of the simulations; however, the low IN concentration run still has appreciable rain $\left(\sim 0.15 \mathrm{~g} \mathrm{~m}^{-3}\right.$ in Fig. $\left.15 \mathrm{c}\right)$.

The reason for the non-linearity in peak ice concentration is that when ice nuclei concentrations are low the HM process acts to multiply the primary ice number concentration by a certain factor until there is no liquid water left for riming, whereas when IN concentrations are high the same happens, but there is also a rapid Bergeron-Findeison process, which quickly evaporates liquid water, leaving little available for the HM process. In between there is a balance where the highest concentrations can be reached.

It should be noted that in all of the ACPIM runs (apart from the $100 \times$ IN run) the precipitation pathway was via the warm rain process. This was not the case for the WRF simulation where, because of a mis-representation of the time-evolution of droplet number concentration and due to an overestimation of the number of ice crystals, the precipitation occurred predominantly via the aggregation and riming of ice crystals. In this case the warm rain was responsible for over an order of magnitude more of the precipitation than the ice processes. However, in the $100 \times$ IN case significant precipitation occurred without warm rain. This was because ice crystal concentrations became large enough to grow by aggregation and then to start to precipitate, while also riming effectively (i.e. riming snow). Interestingly the highest value of the primary IN number does not produce the most ice crystals in the modelled cloud. The reason for this is that a rapid Bergeron-Findeison process results in the evaporation of liquid water and switches off the Hallett-Mossop process.

\section{Summary of model results}

A combined modelling and observation study was used to investigate the role of the Hallett-Mossop secondary ice production process in terms of its influence on precipitation from a winter-time shallow convective cloud region over the southern part of the UK. Whilst the WRF model results showed some increase in the spatial extent of precipitation occurrence due to inclusion of the Hallett-Mossop process, the treatment of primary ice nucleation was found to have the most significant control on precipitation, at least in this particular case.

The WRF model was able to reproduce total ice number concentrations of several per litre even in the absence of the Hallett-Mossop process, which was sufficient to sustain precipitation as the convective cells were advected eastwards towards the Chilbolton region. However, these high concentrations of primary ice were generated because the model achieved significantly colder cloud top temperatures than were actually observed, effectively reducing the model sensitivity to the HM process. This was due to the inability of the model to capture the temperature inversion observed at $2 \mathrm{~km}$. This problem is compounded by the lack of a prognostic treatment of IN in the model, which effectively allows ice concentrations to be replenished at each timestep and helps to maintain precipitation in an unrealistic way. These issues serve to highlight the weaknesses associated with this model scheme when simulating supercooled shallow convection common to the UK.

The ACPIM studies in particular found the HM process to be a powerful mechanism for ice production, yielding 3 orders of magnitude more ice than predicted by the DeMott et al. (2010) primary scheme acting alone. Key to the HM process was the importance of having the correct aerosol input and in predicting the correct broadening of the size distribution so that an active collision and coalescence process was enabled. However, interestingly, for a model run with primary ice crystal concentrations that were $100 \times$ the DeMott et al. scheme, significant amounts of precipitation was formed through riming and the HM process was effectively turned off by the Bergeron-Findeisen process removing the droplets through evaporation (e.g. Crosier et al., 2011). The strong sensitivity to the collision kernel suggests that there is still more work to be done to quantify the collision kernel and the effect that turbulence of different intensities has on it.

Chamber studies suggest that dust particles are not very effective IN at these temperatures, but still the concentrations observed in this case may be high enough to give the required number of IN (Fig. 6a, c). In this study WIBS measurements indicated that a significant number of particles in the boundary layer, were very likely biological in origin. However, based on previous laboratory data (Levin and Yankofsky, 1983) the concentrations may not be high enough to explain the primary IN in this case. Without any available cloud particle residual measurements, or airborne bioaerosol measurements this cannot be confirmed.

Finally, ACPIM runs with "high" aerosol number concentrations and thus high droplet concentrations, showed no evidence of ice enhancement over primary ice concentrations. This was as a result of the inability to grow drops of sufficient size in these conditions which could then precipitate through the cloud collecting primary ice particles to form the instant rimer particles required to initiate the $\mathrm{HM}$ splinter production process. This highlights the importance of warm rain production to this secondary ice particle production mechanism (Jameson et al., 1996). As mentioned, for low primary IN concentrations, ACPIM predicted the warm-rain process to be the dominant precipitation pathway, while WRF predicted precipitation to occur via ice aggregation and then riming. Figure. 3, centre, bottom shows that in the observed cloud there was significant liquid water at larger sizes below $0{ }^{\circ} \mathrm{C}$; this gives evidence that the "warm-rain" process was active below $0{ }^{\circ} \mathrm{C}$, and suggests that ACPIM gives a better account of the microphysical processes in this case than WRF. 


\section{Source of the primary ice nuclei}

The DeMott et al. (2010) parameterisation does not explicitly specify the ice nuclei type at these high temperatures, but we may gain some insight from the surface aerosol measurements since it has been demonstrated from the aircraft in situ and remote sensing measurements that there is coupling between the air at the ground and the air just below the inversion (i.e. just below cloud base), and hence with the air entering cloud.

\subsection{IN from the dust fraction of the measured aerosol}

Using the ice nuclei surface area dependent active sites concept described in Connolly et al. (2009); Niemand et al. (2012) have investigated a range of mineral dusts and found that the surface site density shows a similar dependence for all of the dusts investigated at temperatures lower than $-10^{\circ} \mathrm{C}$. At $-10^{\circ} \mathrm{C}$ the best fit to aerosol surface site density, $n_{\mathrm{s}}$ is $\sim 1 \times 10^{6} \mathrm{~m}^{-2}$ and extrapolation down to $-5^{\circ} \mathrm{C}$ suggests that samples, such as Saharan dust, could have a value of $n_{\mathrm{s}}$ as high as $\sim 1 \times 10^{7} \mathrm{~m}^{-2}$ since there is significant spread in the data at high temperatures.

We can therefore estimate the number ice nuclei, nin, that are supplied by the dust fraction of the aerosol size distribution (see Fig. 6a and c) as follows:

$\operatorname{nin}=\int_{0.6}^{D_{\max }} \frac{d N(D)}{d D} \times\left(1-\exp \left[-\frac{\pi D^{2}}{4} \times n_{\mathrm{s}}\right]\right) f_{\mathrm{a}}(D) d D$

where $n_{\mathrm{S}}$ is the number of ice active sites per unit area of a dust particle (as a function of temperature), $f_{\mathrm{a}}(D)$ is the sizedependent fraction of the aerosol size distribution that is dust (Fig. 6c) and $D$ is the diameter of the aerosol particle (for simplicity particles are assumed to be spherical in this case). A description of the derivation is provided in Connolly et al. (2009) (see Eq. (9) of that paper).

Applying Eq. (1) to the observed aerosol properties, Fig. 6, yields a primary ice crystal concentration due to mineral dust nucleation of $\sim 1 \times 10^{-2} \mathrm{~L}^{-1}$. It is worth noting that the DeMott parameterisation for these data yields concentrations between $1 \times 10^{-2}$ and $1 \times 10^{-1} \mathrm{~L}^{-1}$ at -5 and $-10^{\circ} \mathrm{C}$ respectively (note that cloud top was $\sim-7.5^{\circ} \mathrm{C}$ ). If we assume that the DeMott parameterisation gives accurate values of IN, then the moderate concentrations of dust in this case are high enough to conclude that dust is a likely source of the IN.

\subsection{IN from the biological fraction of the measured aerosol}

Biological particle size distributions $\left(0.5<D_{\mathrm{p}}<20 \mu \mathrm{m}\right)$ were also measured at the surface site (see Fig. 6) using the WIBS instrument. In order to estimate the concentrations of ice nuclei due to these particles we assume (in this environment) that fluorescent particles with diameter less than $\sim 10 \mu \mathrm{m}$ in diameter were of mainly single bacteria, bacterial clumps or small spores, while those greater than $10 \mu \mathrm{m}$ were mainly pollen (e.g. Burrows et al., 2009). We then use available literature to estimate their activity in the freezing mode.

A study of drop freezing by Levin and Yankofsky (1983) reported that drops of size $1 \mathrm{~mm}$ that contained, on average, $1 \times 10^{6}$ bacteria particles per drop had $\sim 50 \%$ ice active fractions at $-5^{\circ} \mathrm{C}$, which means effectively 1 in $1 \times 10^{7}$ million bacteria may be active as an ice nucleus. At $-10^{\circ} \mathrm{C}$, $100 \%$ were active (i.e. the ice active fraction was 1 in 5 million). The WIBS reported concentrations of biological particles of $\sim 0.1 \mathrm{~cm}^{-3}$ during the aircraft flights $\left(D_{p}<10 \mu \mathrm{m}\right.$, see Fig. 6a and c) and hence the ice active number concentration can be estimated using ratios from the Levin and Yankofsky study: $\sim \frac{1}{1 \times 10^{7}} \times 0.1 \mathrm{~cm}^{-3} \cong 1 \times 10^{-5} \mathrm{~L}^{-1}$. This is far less than the IN resulting from the mineral dust (previous section). Note that this assumes that one biological "particle" will consist of, or carry, a single bacterium (rather than having several bacteria or clumps of bacteria per particle). This is a reasonable assumption when considering the typical size of a bacterium (a few microns) which is comparable to the size of the observed aerosol. Since the measured concentrations of particles larger than $10 \mu \mathrm{m}$ diameter are negligible and due to the fact the case was in January we have ruled out possible contributions to the IN from pollen.

However, it was found by Möhler et al. (2008) that pseudomonas Syringae bacteria were active as ice nuclei at $-8^{\circ} \mathrm{C}$ and could account for IN concentrations of around $0.01 \mathrm{~L}^{-1}$ although we do not have any measurements specific to this species of bacteria. Further, Conen et al. (2011) found that soil particles which consisted of a mixture of mineral and biological material were sometimes able to act as ice nuclei at temperatures as high as $-7{ }^{\circ} \mathrm{C}$ and fungi, lichen and plant fragments have also been shown to act as ice nuclei (Després et al., 2012).

Möhler et al. (2008) determined the ice active fraction of several biological aerosol where they derived a typical ice active fraction of $10^{-4}$ over the examined bio aerosols active temperature range of $-7^{\circ} \mathrm{C}$ and $-11^{\circ} \mathrm{C}$. Applying this suggested ice active fraction to the average WIBS PBAP number concentration $\left(\sim 0.1 \mathrm{~cm}^{-3}\right)$ yields an IN concentration of $0.01 \mathrm{~L}^{-1}$. Further, Conen et al. (2011) found that soil particles which consisted of a mixture of mineral and biological material were sometimes able to act as ice nuclei at temperatures as high as $-7{ }^{\circ} \mathrm{C}$ and fungi, lichen and plant fragments have also been shown to act as ice nuclei (Després et al., 2012).

While inconclusive, due to the lack of aircraft in situ biological particle data to constrain the estimated biological and non-biological IN concentrations, calculations based on laboratory data and the observed bioaerosol concentrations at the surface, allow us to suggest that it is entirely plausible that a significant fraction of the primary ice nuclei at the observed temperatures could be of biological origin. However, 
this is limited by the choice of laboratory study used to constrain the ice active fraction of the biological aerosol and we suggest that more laboratory studies are required if the influence of biological aerosol acting as atmospherically releveant IN is to be understood.

\section{The Hallett-Mossop secondary production mechanism}

All of the in situ observations performed during this study displayed enhanced ice crystal number concentrations that cannot be explained by primary nucleation alone. Calculated vertical profiles of predicted ice nuclei number concentrations in the observation region predict maximum values of $\sim 0.1 \mathrm{~L}^{-1}$ for the DeMott scheme and $1.2 \mathrm{~L}^{-1}$ for the Meyers scheme. However, the in situ microphysical observations revealed regions of cloud which contained over an order of magnitude more ice than can be predicted using either scheme. In the regions of enhanced ice number concentrations, 2DS images displayed a significant number of small columnar crystals coexisting with droplets and graupel suggesting secondary ice production via the Hallett-Mossop rime splintering process was possible and probably occurring. To test this, equation 1 of Harris-Hobbs and Cooper (1987) was applied to the data using the approach described by Crosier et al. (2011). First an "observed" splinter production rate was computed using the ice particle size distribution observed within the HM zone (Run R3, $34 \mathrm{~km}$ from CFARR) which displayed a small mode of columns with sizes ranging from 45 to $145 \mu \mathrm{m}$ in length. Assuming an ice crystal growth rate of $0.4 \mu \mathrm{m} \mathrm{s}^{-1}$ at $-3.5^{\circ} \mathrm{C}$ (e.g. Ryan et al., 1976) this would equate to an elapsed time of 250 seconds for the crystals to grow across the size range observed, under steady state, water saturated conditions. This implies a required splinter production rate of $\sim 80 \mathrm{~m}^{-3} \mathrm{~s}^{-1}$ in order to maintain the observed crystal concentrations.

The Harris-Hobbs and Cooper equations were then used to predict a splinter production rate using the observed cloud droplet size distribution from run $\mathrm{R} 1$ as being representative of the supercooled droplet distribution observed below the HM boundary. The 2DS ice size distributions from run R3 (35.1 km-33.6 km from CFARR) were used as representative of the riming ice distribution. For a droplet-ice collection efficiency of 1.0, the predicted splinter production rate was calculated to be $40.2 \mathrm{~m}^{-3} \mathrm{~s}^{-1}$. Applying the droplet-ice collection efficiency of Beard and Grover (1974) reduced this production rate to $28.8 \mathrm{~m}^{-3} \mathrm{~s}^{-1}$. These results cannot quite be reconciled with the "observed" splinter production rate. We therefore examined the effect of relaxing the condition that requires large droplets $(D>24 \mu \mathrm{m})$ to be present to enable splinter production to occur as they rime. Reducing the large droplet limit to $D>22 \mu \mathrm{m}$ yielded a production rate of $120 \mathrm{~m}^{-3} \mathrm{~s}^{-1}\left(72.7 \mathrm{~m}^{-3} \mathrm{~s}^{-1}\right.$ with the B\&G collection efficiency), whilst a further reduction to $D>20 \mu \mathrm{m}$ gave a pre- dicted rate of $320 \mathrm{~m}^{-3} \mathrm{~s}^{-1}\left(200 \mathrm{~m}^{-3} \mathrm{~s}^{-1}\right.$ with $\left.\mathrm{B} \& \mathrm{G}\right)$, which is too large a rate. Clearly relaxing the large droplet constraint improves the agreement between the observed and predicted splinter production rates, which is consistent with the results of Crosier et al.. This study shows that reconciliation between model and observations which require identification of the exact $\mathrm{H}-\mathrm{M}$ droplet size onset criteria places significant constraints on the sizing tolerance required for airborne cloud spectrometers. Based on the results of the detailed laboratory calibrations by Lance et al. (2010), it can be argued that the maximum uncertainty in the size calibration could possibly allow for a shift of up to $2 \mu \mathrm{m}$ in the CDP. Reducing the critical drop size may not be an unreasonable step to take; laboratory experiments by Choularton et al. (1978, 1980) showed photographic evidence for protuberances occurring on droplets as small as 10 and $15 \mu \mathrm{m}$ in diameter, suggesting that small droplets can undergo symmetrical freezing to create an ice shell, which may subsequently fracture and produce splinters. However, this also highlights the accuracy which airborne instrumentation must achieve for absolute size measurements of droplets, particularly in mixed phase conditions, i.e. to significantly better resolution than $2 \mu \mathrm{m}$, in order to investigate secondary ice processes. Laboratory studies are planned to further investigate and refine this aspect of the Hallett-Mossop process.

\section{Conclusions}

The package of high-resolution ground, remote sensing and aircraft observations of convective clouds we present here examines a case close to the so-called ice "multiplication boundary" described by Mossop (1978). The multiplication boundary is defined by the cloud-base temperature, temperature profile and droplet number concentration that determines whether HM multiplication can or cannot proceed effectively. We have investigated this region in detail and show how measured aerosol properties below cloud base can, with care, be used to model and interpret the subsequent microphysical processes occurring within such shallow convective clouds.

We applied the ACPIM cloud parcel model to reveal how the ice phase and precipitation within aged, slightly supercooled cumulus cloud systems develop, and looked at the influence both the HM process and primary ice nucleation mechanisms have on these.

The results obtained emphasise the importance of and sensitivity to aerosols, primary ice nuclei, and the need for accurate ice nuclei concentration measurements as well as accurate descriptions of microphysical process rates.

It is concluded the observed rapid glaciation of the cloud could only be explained by secondary ice from the HallettMossop process and that this required the development of supercooled drizzle droplets which froze by capturing ice crystals turning into instant rimers. 
To initiate the ice phase a small amount of primary ice nucleation was required (in concentrations of about $0.01 \mathrm{~L}^{-1}$ ) at $-7.5^{\circ} \mathrm{C}$. The results suggest that in this case the most likely source of the ice nuclei were dust particles. Significant concentrations of Biological particles were present and it is possible that these also contributed to the ice nuclei. The ice nuclei were adequately represented by the DeMott et al. (2010) parameterisation. The power of secondary ice particle production by the Hallett-Mossop process in producing large numbers of ice crystals at temperatures around $-6^{\circ} \mathrm{C}$ emphasises the need to understand ice nucleation in slightly supercooled clouds even though the number of ice particles produced by primary ice nuclei may be small.

In contrast WRF model simulations found the precipitation from the cloud was not strongly sensitive to secondary ice via the Hallett-Mossop process since ice formed by primary nucleation was able to produce the intensity of precipitation observed. Including secondary ice processes however does modify the spatial distribution of simulated precipitation in the WRF model. The WRF simulations overestimated the concentrations of primary IN because the model was unable to resolve the inversion at the observed cloud top and so generated cloud top temperatures lower than observed, it does not contain prognostic ice nuclei and so is not suitable for simulating the microphysics of these clouds.

Acknowledgements. This work was funded by the NERC APPRAISE programme, grant number NE/E01125X/1. Christopher Dearden was funded by NERC studentship NE/F00821X/1 in a case award with the Met Office. We would like to acknowledge the support from FGAM, FAAM and Direct Flight in obtaining the aircraft dataset. We would also like to thank the following for supporting the CFARR measurements: Andrew Barrett (University of Reading), Darcy Ladd and Charles Wrench (CFARR). MODIS data were obtained from the NASA LAADS online archive (http://ladsweb.nascom.nasa.gov/). Coastline data were obtained from the online NOAA coastline extractor (http://rimmer.ngdc.noaa.gov/). Radiosonde data were obtained from the University of Wyoming Sounding Archive (http://weather.uwyo.edu/upperair/sounding.html).

Edited by: E. Weingartner

\section{References}

Allan, J. D.: A generalized method for the extraction of chemically resolved mass spectra from Aerodyne aerosol mass spectrometer data, J. Aerosol Sci., 35, 909-922, 2004.

Ansmann, A., Tesche, M., Althausen, D., Müller, D., Seifert, P., Freudenthaler, V., Heese, B., Wiegner, M., Pisani, G., Knippertz, P., and Dubovik, O.l: Influence of Saharan dust on cloud glaciation in southern Morocco during the Saharan Mineral Dust Experiment, J. Geophys. Res., 113, D04210, doi:10.1029/2007JD008785, 2008.

Bacsi, A., Choudhury, B. K., Dharajiya, N., Sur, S., and Boldogh, I.: Subpollen particles: carriers of allergenic pro- teins and oxidases, J. Allergy Clin. Immunol., 118, 844-850, doi:10.1016/j.jaci.2006.07.006, 2006.

Bigg, E. K.: The formation of atmospheric ice crystals by the freezing of droplets, Quarterly J. Roy. Meteorol. Soc., 79, 510-519, doi:10.1002/qj.49707934207, 1953.

Blyth, A. M. and Latham, J.: Development of ice and precipitation in New Mexican summertime cumulus clouds, Q. J. Roy. Meteorol. Soc., 119, 91-120, doi:10.1002/qj.49711950905, 1993.

Bott, A.: A Flux Method for the Numerical Solution of the Stochastic Collection Equation: Extension to Two-Dimensional Particle Distributions, J. Atmos. Sci., 57, 284-294, doi:10.1175/15200469(2000)057;0284:AFMFTN $; 2.0 . C O ; 2,2000$.

Bouniol, D., Illingworth, A. J., and Hogan, R. J.: Deriving turbulent kinetic energy dissipation rate within clouds using ground based $94 \mathrm{GHz}$ radar, in: 31st AMS conference on Radar Meteorology, 2003.

Bower, K., Moss, S., Johnson, D., Choularton, T., Latham, J., Brown, R., Blyth, A., and Cardwell, J.: A parametrization of the ice water content observed in frontal and convective clouds, Q. J. Roy. Meteorol. Soc., 122, 1815-1844, 1996.

Burrows, S. M., Butler, T., Jöckel, P., Tost, H., Kerkweg, A., Pöschl, U., and Lawrence, M. G.: Bacteria in the global atmosphere - Part 2: Modeling of emissions and transport between different ecosystems, Atmos. Chem. Phys., 9, 9281-9297, doi:10.5194/acp-9-9281-2009, 2009.

Chen, J.-P. and Lamb, D.: The Theoretical Basis for the Parameterization of Ice Crystal Habits: Growth by Vapor Deposition, Journal of the Atmospheric Sciences, 51, 1206-1222, doi:10.1175/1520-0469(1994)051<1206:TTBFTP>2.0.CO;2, 1994a.

Chen, J.-P. and Lamb, D.: Simulation of Cloud Microphysical and Chemical Processes Using a Multicomponent Framework. Part I: Description of the Microphysical Model, J. Atmos. Sci., 51, 2613-2630, doi:10.1175/15200469(1994)051<2613:SOCMAC > 2.0.CO;2, 1994b.

Choularton, T. W., Latham, J., and Mason, B. J.: A possible mechanism of ice splinter production during riming, Nature, 274, 791792, doi:10.1038/274791a0, 1978.

Choularton, T. W., Griggs, D. J., Humood, B. Y., and Latham, J.: Laboratory studies of riming, and its relation to ice splinter production, Quarterly Journal of the Royal Meteorological Society, 106, 367-374, doi:10.1002/qj.49710644809, 1980.

Conen, F., Morris, C. E., Leifeld, J., Yakutin, M. V., and Alewell, C.: Biological residues define the ice nucleation properties of soil dust, Atmos. Chem. Phys., 11, 9643-9648, doi:10.5194/acp-119643-2011, 2011.

Connolly, P. J., Möhler, O., Field, P. R., Saathoff, H., Burgess, R., Choularton, T., and Gallagher, M.: Studies of heterogeneous freezing by three different desert dust samples, Atmos. Chem. Phys., 9, 2805-2824, doi:10.5194/acp-9-2805-2009, 2009.

Connolly, P. J., Emersic, C., and Field, P. R.: A laboratory investigation into the aggregation efficiency of small ice crystals, Atmos. Chem. Phys., 12, 2055-2076, doi:10.5194/acp-12-20552012, 2012.

Cooper, W.: Ice initiation in natural clouds. Precipitation enhancement: A Scientific Challenge, Am. Meteorol. Soc., 43, 29-32, 1986.

Crosier, J., Bower, K. N., Choularton, T. W., Westbrook, C. D., Connolly, P. J., Cui, Z. Q., Crawford, I. P., Capes, G. L., Coe, H., 
Dorsey, J. R., Williams, P. I., Illingworth, A. J., Gallagher, M. W., and Blyth, A. M.: Observations of ice multiplication in a weakly convective cell embedded in supercooled mid-level stratus, Atmos. Chem. Phys., 11, 257-273, doi:10.5194/acp-11-257-2011,

Dearden, C., Connolly, P. J., Choularton, T. W., and Field, P. R.: Evaluating the effects of microphysical complexity in idealised simulations of trade wind cumulus using the Factorial Method, Atmos. Chem. Phys., 11, 2729-2746, doi:10.5194/acp-11-27292011,2011.

DeMott, P. J., Sassen, K., Poellot, M. R., Baumgardner, D., Rogers, D. C., Brooks, S. D., Prenni, A. J., and Kreidenweis, S. M.: African dust aerosols as atmospheric ice nuclei, Geophys. Res. Lett., 30, 1732, doi:10.1029/2003GL017410, 2003.

DeMott, P. J., Prenni, A. J., Liu, X., Kreidenweis, S. M., Petters, M. D., Twohy, C. H., Richardson, M. S., Eidhammer, T., and Rogers, D. C.: Predicting global atmospheric ice nuclei distributions and their impacts on climate, Proc. Natl. Acad. Sci. USA, 107, 11217-11222, doi:10.1073/pnas.0910818107, 2010.

Després, V. R., Huffman, A. J., Burrows, S. M, Hoose, C., Safatov. A. S., Buryak, G., Fröhlich-Nowoisky, J., Elbert, W., Pöschl. U., and Jaenicke., R.: Primary biological aerosol particles in the atmosphere: a review, Tellus B, 64, 2012

Diehl, K., Matthias-Maser, S., Jaenicke, R., and Mitra, S. K.: The ice nucleating ability of pollen: Part II. Laboratory studies in immersion and contact freezing modes, Atmos. Res., 61, 125-133, 2002

Diehl, K., Simmel, M., and Wurzler, S.: Numerical sensitivity studies on the impact of aerosol properties and drop freezing modes on the glaciation, microphysics, and dynamics of clouds, J. Geophys. Res., 111, D07202, doi:10.1029/2005JD005884,2006.

Forster, P., Ramaswamy, V., Artaxo, P., Berntsen, T., Betts, R., Fahey, D., Haywood, J., Lean, J., Lowe, D., Myhre, G., Nganga, J., Prinn, R., Raga, G., Schulz, M., and Van Dorland, R.: Changes in Atmospheric Constituents and in Radiative Forcing. In: Climate Change 2007: The Physical Science Basis. Contribution of Working Group I to the Fourth Assessment Report of the Intergovernmental Panel on Climate Change, Cambridge University Press, 2007.

Fukuta, N.: Experimental Studies on the Growth of Small Ice Crystals, Journal of the Atmospheric Sciences, 26, 522-531, doi:10.1175/1520-0469(1969)026<0522:ESOTGO > 2.0.CO;2, 1969.

Gabey, A. M., Gallagher, M. W., Whitehead, J., Dorsey, J. R., Kaye, P. H., and Stanley, W. R.: Measurements and comparison of primary biological aerosol above and below a tropical forest canopy using a dual channel fluorescence spectrometer, Atmos. Chem. Phys., 10, 4453-4466, doi:10.5194/acp-10-4453-2010, 2010.

Goddard, J. W. F., Eastment, J. D., and Thurai, M.: The Chilbolton advanced meteorological radar: a tool for multidisciplinary atmospheric research, Electr. Comm. Eng. J., 6, 77-86, 1994.

Gregory, P.: The microbiology of the atmosphere, Interscience Publishers, New York, USA, 2nd edn., 1973.

Hall, W. D.: A Detailed Microphysical Model Within a Two-Dimensional Dynamic Framework: Model Description and Preliminary Results, Journal of the Atmospheric Sciences, 37, 2486-2507, doi:10.1175/15200469(1980)037<2486:ADMMWA>2.0.CO;2, 1980.

Hallett, J. and Mossop, S. C.: Production of secondary ice particles during the riming process, Nature, 249, 26-28, 1974.
Harris-Hobbs, R. L. and Cooper, W. A.: Field Evidence Supporting Quantitative Predictions of Secondary Ice Production Rates, Journal of the Atmospheric Sciences, 44, 1071-1082, doi:10.1175/1520-0469(1987)044<1071:FESQPO>2.0.CO;2, 1987.

Hogan, R. J., Field, P. R., Illingworth, A. J., Cotton, R. J., and Choularton, T. W.: Properties of embedded convection in warm-frontal mixed-phase cloud from aircraft and polarimetric radar, Q. J. Roy. Meteorol. Soc., 128, 451-476, doi:10.1256/003590002321042054, 2002.

Huang, X.-Y., Xiao, Q., Barker, D. M., Zhang, X., Michalakes, J., Huang, W., Henderson, T., Bray, J., Chen, Y., Ma, Z., Dudhia, J., Guo, Y., Zhang, X., Won, D.-J., Lin, H.-C., and Kuo, Y.-H.: FourDimensional Variational Data Assimilation for WRF: Formulation and Preliminary Results, Mon. Weather Rev., 137, 299-314, doi:10.1175/2008MWR2577.1,2009.

Illingworth, A. J., Hogan, R. J., O’Connor, E. J., Bouniol, D., Delanoë, J., Pelon, J., Protat, A., Brooks, M. E., Gaussiat, N., Wilson, D. R., Donovan, D. P., Baltink, H. K., van Zadelhoff, G.-J., Eastment, J. D., Goddard, J. W. F., Wrench, C. L., Haeffelin, M., Krasnov, O. A., Russchenberg, H. W. J., Piriou, J.-M., Vinit, F., Seifert, A., Tompkins, A. M., and Willén, U.: Cloudnet - Continuous Evaluation of Cloud Profiles in Seven Operational Models Using Ground-Based Observations, B. Am. Meteorol. Soc., 88, 883-898, doi:10.1175/BAMS-88-6-883, 2007.

Jacobson, M.: Fundamentals of Atmospheric Modeling, Cambridge University Press, New York, USA, 2nd edn., doi:10.2277/0521548659, 2005.

Jameson, A. R., Murphy, M. J., and Krider, E. P.: MultipleParameter Radar Observations of Isolated Florida Thunderstorms during the Onset of Electrification, Journal of Applied Meteorology, 35, 343-354, doi:10.1175/1520 0450(1996)035<0343:MPROOI > 2.0.CO;2, 1996.

Kaye, P., Stanley, W. R., Hirst, E., Foot, E. V., Baxter, K. L., and Barrington, S. J.: Single particle multichannel bio-aerosol fluorescence sensor, Opt. Express, 13, 3583-3593, 2005.

Khairoutdinov, M. and Kogan, Y. L.: A new cloud physics parameterisation in a large-eddy simulation model of marine stratocumulus, Mon. Weather Rev., 128, 229-243, 2000.

Kovetz, A. and Olund, B.: The Effect of Coalescence and Condensation on Rain Formation in a Cloud of Finite Vertical Extent, Journal of the Atmospheric Sciences, 26, 1060-1065, doi:10.1175/1520-0469(1969)026<1060:TEOCAC > 2.0.CO;2, 1969.

Lance, S., Brock, C. A., Rogers, D., and Gordon, J. A.: Water droplet calibration of the Cloud Droplet Probe (CDP) and inflight performance in liquid, ice and mixed-phase clouds during ARCPAC, Atmos. Meas. Tech., 3, 1683-1706, doi:10.5194/amt3-1683-2010, 2010..

Lanz, V. A., Alfarra, M. R., Baltensperger, U., Buchmann, B., Hueglin, C., and Prévôt, A. S. H.: Source apportionment of submicron organic aerosols at an urban site by factor analytical modelling of aerosol mass spectra, Atmos. Chem. Phys., 7, 15031522, doi:10.5194/acp-7-1503-2007, 2007.

Lawson, R. P., O’Connor, D., Zmarzly, P., Weaver, K., Baker, B., Mo, Q., and Jonsson, H.: The 2D-S (Stereo) Probe: Design and Preliminary Tests of a New Airborne, High-Speed, HighResolution Particle Imaging Probe, J. Atmos. Ocean. Technol., 23, 1462-1477, doi:10.1175/JTECH1927.1, 2006. 
Levin, Z. and Yankofsky, S. A.: Contact Versus Immersion Freezing of Freely Suspended Droplets by Bacterial Ice Nuclei, Journal of Climate and Applied Meteorology, 22, 1964-1966, doi:10.1175/1520-0450(1983)022<1964:CVIFOF > 2.0.CO;2, 1983.

Libbrecht, K. G.: The physics of snow crystals, Rep. Prog. Phys., 68, 855, doi:10.1088/0034-4885/68/4/R03, 2005.

Marshall, J. S. and Palmer, W. M. K.: THE DISTRIBUTION OF RAINDROPS WITH SIZE, Journal of Meteorology, 5, 165-166, doi:10.1175/1520-0469(1948)005<0165:TDORWS > 2.0.CO;2, 1948.

McFarquhar, G. M., Um, J., Freer, M., Baumgardner, D., Kok, G. L., and Mace, G.: Importance of small ice crystals to cirrus properties: Observations from the Tropical Warm Pool International Cloud Experiment (TWP-ICE), Geophys. Res. Lett., 34, L13803, doi:10.1029/2007GL029865,2007.

Meyers, M. P., DeMott, P. J., and Cotton, W. R.: New Primary Ice-Nucleation Parameterizations in an Explicit Cloud Model, J. Appl. Meteorol., 31, 708-721, 1992.

Möhler, O., Georgakopoulos, D. G., Morris, C. E., Benz, S., Ebert, V., Hunsmann, S., Saathoff, H., Schnaiter, M., and Wagner, R.: Heterogeneous ice nucleation activity of bacteria: new laboratory experiments at simulated cloud conditions, Biogeosciences, 5, 1425-1435, doi:10.5194/bg-5-1425-2008, 2008.

Morcrette, C., Lean, H., Browning, K., Nicol, J., Roberts, N., Clark, P., Russell, A., and Blyth, A.: Combination of Mesoscale and Synoptic Mechanisms for Triggering an Isolated Thunderstorm: Observational Case Study of CSIP IOP 1, Mon. Weather Rev., 135, 3728-3749, doi:10.1175/2007MWR2067.1, 2007.

Morrison, H., Curry, J. A., and Khvorostyanov, V. I.: A New Double-Moment Microphysics Parameterization for Application in Cloud and Climate Models. Part I: Description, J. Atmos. Sci., 62, 1665-1677, doi:10.1175/JAS3446.1, 2005.

Mossop, S. C.: Some Factors Governing Ice Particle Multiplication in Cumulus Clouds, J. Atmos. Sci., 35, 2033-2037, doi:10.1175/1520-0469(1978)035<2033:SFGIPM>2.0.CO;2, 1978.

Mossop, S. C., Cottis, R. E., and Bartlett, B. M.: Ice crystal concentrations in cumulus and stratocumulus clouds, Q. J. Roy. Meteorol. Soc., 98, 105-123, doi:10.1002/qj.49709841509, 1972.

Niemand, M., Möhler, O., Vogel, B., Vogel, H., Hoose, C., Connolly, P. J., Klein, H., Bingemer, H., DeMott, P. J., Skotzki, J., and Leisner, T.: A particle-surface-area-based parameterisation of immersion freezing on mineral dust particles, J. Atmos. Sci., doi:10.1175/JAS-D-11-0249.1, in press.

Penner, J., Andreae, M., Annegarn, H., Barrie, L., Feichter, J., Hegg, D., Jayaraman, A., Leaitch, R., Murphy, D., Nganga, J., and Pitari, G.: Climate Change 2001: The Scientific Basis: Chapter 6 Radiative Forcing of Climate Change, 2001.
Phillips, V. T. J., DeMott, P. J., and Andronache, C.: An Empirical Parameterization of Heterogeneous Ice Nucleation for Multiple Chemical Species of Aerosol, J. Atmos. Sci., 65, 2757-2783, 2008.

Phillips, V. T. J., Blyth, A. M., Brown, P. R. A., Choularton, T. W., and Latham, J.: The glaciation of a cumulus cloud over New Mexico, Q. J. Roy. Meteorol. Soc., 127, 1513-1534, 2001.

Pinsky, M., Khain, A., and Shapiro, M.: Collisions of Small Drops in a Turbulent Flow. Part I: Collision Efficiency. Problem Formulation and Preliminary Results, J. Atmos. Sci., 56, 2585-2600, 1999.

Pruppacher, H. and Klett, J.: Microphysics of Clouds and Precipitation, Kluwer Academic Publishers, Dordrecht, The Netherlands, 2nd edn., 1997.

Ryan, B. F., Wishart, E. R., and Shaw, D. E.: The Growth Rates and Densities of Ice Crystals between $-3^{\circ} \mathrm{C}$ and $-21^{\circ} \mathrm{C}$, J. Atmos. Sci., 33, 842-850, doi:10.1175/15200469(1976)033<0842:TGRADO>2.0.CO;2, 1976.

Sassen, K., DeMott, P. J., Prospero, J. M., and Poellot, M. R.: Saharan dust storms and indirect aerosol effects on clouds: CRYSTAL-FACE results, Geophys. Res. Lett., 30, 1633, doi:10.1029/2003GL017371, 2003.

Saunders, C. P. R. and Hosseini, A. S.: A laboratory study of the effect of velocity on Hallett-Mossop ice crystal multiplication, Atmos. Res., 59-60, 3-14, 2001.

Seifert, A. and Beheng, K. D.: A two-moment cloud microphysics parameterization for mixed-phase clouds. Part 1: Model description, Meteorol. Atmos. Phys., 92, 45-66, 2006.

Stokes, R. H. and Robinson, R. A.: Interactions in Aqueous Nonelectrolyte Solutions. I. Solute-Solvent Equilibria, J. Phys. Chem., 70, 2126-2131, doi:10.1021/j100879a010, 1966.

Topping, D. O., McFiggans, G. B., and Coe, H.: A curved multicomponent aerosol hygroscopicity model framework: Part 1: Inorganic compounds, Atmos. Chem. Phys., 5, 1205-1222, doi:10.5194/acp-5-1205-2005, 2005.

Ulbrich, I. M., Canagaratna, M. R., Zhang, Q., Worsnop, D. R., and Jimenez, J. L.: Interpretation of organic components from Positive Matrix Factorization of aerosol mass spectrometric data, Atmos. Chem. Phys., 9, 2891-2918, doi:10.5194/acp-9-2891-2009, 2009.

Westbrook, C. D. and Illingworth, A. J.: Evidence that ice forms primarily in supercooled liquid clouds at temperatures $>-27^{\circ} \mathrm{C}$, Geophys. Res. Lett., 38, L14808, doi:10.1029/2011GL048021, 2011.

Westbrook, C. D., Ball, R. C., Field, P. R., and Heymsfield, A. J.: Universality in snowflake aggregation, Geophys. Res. Lett., 31, L15104, doi:10.1029/2004GL020363,2004.

Whitby, K. T.: The physical characteristics of sulfur aerosols, Atmos. Environ., 12, 135-159, 1978. 